\title{
Sermet Muhtar Alus ve Türk Tiyatrosu*
}

\author{
Yakup ÖZTÜRK**
}

\section{$\ddot{O}_{z}$}

Batılı anlamda tiyatro Türk kültür hayatına Tanzimat sonrasında sahne faaliyeti ve edebiyatın bir türü olarak girmiştir. Batılılaşmanın Türk edebiyatında en görünür cephesi olan tiyatro bu yıllarda devlet adamlarından sanatçılara kadar hemen her kesimin dikkatini çekmiştir. Bizzat oyun yazarak tiyatroya katkı sağlandığg gibi, bu türe derin bir dikkat gösteren, tiyatronun bütün unsurlarıyla ilgilenen yazarlar da olmuştur. Bu dünyaya tanık olan isimlerden biri de ömrünün son yirmi yılını her gün gazetelerde geçmiş zamanların İstanbul'unu yazmaya adamış Sermet Muhtar Alus'tur. Hem gazete yazılarında hem de romanlarında 1850'lerden Darülbedayi'nin çalışmaları da dâhil olmak üzere Osmanlı tiyatrosunu tanıklıklara dayanarak anlatmıştır. Onun söz konusu metinlerden derlenecek tiyatro yorumları genel geçer tiyatro tarihlerinin ötesindedir. Bu metinleri, yazarının tecrübe ettiği gözlem ve yorumlar değerli kılmaktadır. Bu çalışmada Alus'un gazete yazılarına yansıyan tiyatro toplulukları, figürleri ve olayları değerlendirilecektir. Sonrasında Türk ve gayrimüslim sanatçıların Alus'un yazılarına yansımaları, yabancı tiyatro topluluklarının faaliyetleri ve tiyatro, Karagöz, meddah sergilerine mekân olmuş yapılardan söz edilecektir. Hikâye ve romanlar çalışmanın hacmini katlayacağından makale dışında tutulmuştur.

Anahtar Kelimeler: Türk Tiyatro Tarihi, Osmanlı Tiyatrosu, Tuluat, Ortaoyunu, Kumpanya, Direklerarası.

\footnotetext{
* Sermet Muhtar Alus'un Eserlerinde İstanbul Mekân-Kimlik-Hafıza başlıklı doktora tezi esas alınarak hazırlanmıştır. ** Dr. Öğr. Üyesi, Bilecik Şeyh Edebali Üniversitesi, Fen-Edebiyat Fakültesi, Türk Dili ve Edebiyatı Bölümü. Bilecik, Türkiye. Elmek: yakup.ozturk@bilecik.edu.tr https://orcid.org/0000-0003-3840-4177
} 


\title{
Sermet Muhtar Alus and Turkish Theatre
}

\begin{abstract}
After the Tanzimat, in the Ottoman society, the theater continued its traditional stage activities as well as the rapidly developed, text-based, sparkling games with western style plays and staging. Copyright stage plays were written and translated into classical and contemporary texts of western literature. NonMuslim artists wrote plays and cantons around their own cultures. The first Turkish theater in Western style was established in Gedikpaşa with the name of the Ottoman Theater, but this structure was destroyed after the performance of the Çerkes Özdenleri. Until the proclamation of the constitutional monarchy, the theater was dominated by tradition, but on the other hand it used the western technique. This shows that it has a hybrid structure. Ortaoyunu, Karagöz and tuluat tried to meet the need of modern theater for the censoring of western style theater. In this respect, the literature of the Turkish theater has been shaped by analyzing the texts written by the writers, rather than stage activities, but there is a very moving theater world especially in Istanbul. Sermet Muhtar Alus was the witness of this world. He wrote about Istanbul every day in the last twenty years of his life. Alus shows in his newspaper articles and novels that he witnessed the history of the Ottoman theater. His writings are more important than many studies on the history of the theatre. These texts are valuable thanks to the observations and comments. In this study, theater groups, figures and events reflected in Alus's newspaper articles will be evaluated. Afterwards, the reflections of Turkish and non-Muslim artists on Alus's writings, activities of foreign theater groups and theater, and the buildings where Karagöz and meddah performances were given will be mentioned. Stories and novels are twice as much as newspaper articles. They were therefore excluded from the article.
\end{abstract}

Keywords: History of Turkish Theater, Ottoman Theater, Tuluat, Ortaoyunu, Kumpanya, Direklerarası. 


\section{Extended Abstract}

Theater as a western genre is the first important activity of Turkish modernization in literature. Western Turkish literature began with a play published in 1859. Together with the writers, all levels of the state were interested in theater. The writers aim to form a new society by writing plays. In a society where an independent reader has not yet grown up, innovations have been settled by staging and watching theater plays that can reach hundreds of people at once. Sermet Muhtar Alus, who spent his childhood and early youth in the early 20th century, showed a special interest in theater. In his writings and novels, he included a lot of people, institutions and plays of the traditional and western Turkish theater. The main purpose of this study is to determine the contributions of Alus, known as an Istanbul writer, to the history of the Turkish theater. In this study, answers were searched for the questions about the ways in which Sermet Muhtar Alus originated from the history of the Turkish theater, whether he turned to theater as an audience or as a playwright, and what he prioritized when considering the theater institutions, people or texts. The study also seeks answers to the following question: How are Sermet Muhtar Alus's writings different from the Turkish theater research? Alus was a writer who described what he saw. Does this give him a privilege amongst theatrical researchers? The source of this study is the articles published by Sermet Muhtar Alus in newspapers and magazines. These articles were obtained from libraries that hold periodicals in their collection. The name of the newspapers and journals in which Alus is a member is determined from research books, graduate theses and encyclopedia articles he wrote himself. A doctoral thesis on Sermet Muhtar Alus was published as a book. This thesis focuses on the biography of the author and the analysis of his novels. One of the other works addressed social issues in the author's works. A specific study of Sermet Muhtar Alus and the Turkish theater has not been done before. Therefore, no comparison can be made. However, researches on the history of 
the Turkish theater have been utilized. These studies are classical examinations that consist of expressions in the history of general literature. Sermet Muhtar Alus had some special features that differentiated his attention from the history of the Turkish theater. In the first place, Alus wrote what he saw and recognized the theater groups in which he wrote. He was present in the theater while the plays were staged. Alus was a social historian. He was not interested in the basic principles of biography, and he wrote about the private lives and family relationships of the actors. Alus wrote about what they did after they retired from the theater?. In the methodology of this study, Sermet Muhtar Alus's articles in daily newspaper and magazine collections were compiled and analyzed. The differences between Alus's writings and the scientific studies on the Turkish theater were found. Alus wrote about the details that were not mentioned in these scientific studies. Therefore, his innovations in the history of the Turkish theater were determined. Sermet Muhtar Alus was the son of Ahmed Muhtar Pasha, who served as a bureaucrat in the Ottoman Empire. Thus, he was not economically dependent on a job. At the same time, he spent his time in artistic activities such as theater and music. Alus was a member of an important family so he met many artists at a young age. As he witnessed the development of the Turkish theater and his interest in art, he produced a wide literature. After the proclamation of the Republic, Istanbul was ignored, so people had a nostalgic interest in what happened in the old times. Alus was a "spendthrift" and consumed his wealth in his youth. He became a writer to survive. But this situation is inexplicable with a shortage of livelihoods. This study revealed that Sermet Muhtar Alus wanted to keep alive a rich culture that was left to be forgotten with the Republic. The Western theater entered the Turkish cultural life as a stage activity and literary genre during the Tanzimat period. Theater was the most visible face of western literature and attracted everyone's attention during the Ottoman period, from statesmen to artists. Some writers contributed to the theater by writing plays. Some writers paid deep attention to this genre and were interested in all elements of the theater. After the Tanzimat, in the Ottoman society, the theater continued its traditional stage activities as well as the rapidly developed, text-based, sparkling games with western style plays and 
staging. Copyright stage plays were written and translated into classical and contemporary texts of western literature. Non-Muslim artists wrote plays and cantons around their own cultures. The first Turkish theater in Western style was established in Gedikpaşa with the name of the Ottoman Theater, but this structure was destroyed after the performance of the Çerkes Özdenleri. Until the proclamation of the constitutional monarchy, the theater was dominated by tradition but on the one hand it used the western technique. This shows that it has a hybrid structure. Ortaoyunu, Karagöz and tuluat tried to meet the need of modern theater for the censoring of western style theater. In this respect, the literature of the Turkish theater has been shaped by analyzing the texts written by the writers, rather than the stage activities, but there is a very moving theater world especially in Istanbul. Sermet Muhtar Alus was the witness of this world. Sermet Muhtar Alus, who lived between 1887 and 1952, wrote articles about Istanbul in daily newspapers and dedicated his life to this from the beginning of the 1930s. He wrote about Istanbul every day in the last twenty years of his life. Alus shows that he witnessed the history of the Ottoman theater in his newspaper articles and novels. His writings are more important than many studies on the history of the theatre. These texts are valuable thanks to the observations and comments. In this study, theater groups, figures and events reflected in Alus's newspaper articles will be evaluated. Afterwards, the reflections of Turkish and non-Muslim artists on Alus's writings, activities of foreign theater groups and theater, and the buildings where Karagöz and meddah performances were given will be mentioned. Stories and novels are twice as much as newspaper articles. They were therefore excluded from the article. 



\section{Giriş}

19. asrın meşhur devlet adamı ve âlim Ahmed Cevdet Paşa Osmanlı maliyesinin Sultan Abdülmecid devrinde borçlanmalarla nasıl bir yıkıma uğradığını anlatırken İstanbul'daki sosyal hayatın değişiminden de bahseder. Mısır'dan Dersaadet'e göç eden hıdiv aileleri konaklar ve yalılar satın alarak "ebvâb-1 sefâhati”" açmışlar, Osmanlı devlet adamlarının eşleri ve kızları da bu Mısır “dökültüleri” ile aşık atmaya çalışarak hanelerinin masraflarını aylık üç dört bin altına vardırmışlardır. (Cevdet Paşa 1980: 8) Masrafla beraber borçlanmalar artmış, vükela konaklarında, saray haremlerinde faizle borç veren tüccarlar türemiştir. Sultanların ve kadın efendilerin mücevherlerinin Beyoğlu sarraflarına rehin bırakılması da bu devirde görülmüştür. Kırım Muharebesi bazı bankerleri Osmanlı Hükumeti hesabına Avrupa ülkelerinden borç alacak kadar güçlendirmiştir. (Çıracı-Dökmeci 1990: 33) Bu savaşın tesiri devlet katından halka doğru büyük değişimlere sebep olmuştur.

Kırım muharebesinde İstanbul'a gelen Fransız ve İngiliz askerleri alt1nı su gibi akıtarak bir anda nisbî bir zenginlik getirmişlerdir. Çarşı esnafı ve kuyumcuların Boğaziçi'nde yalılar satın alması bu günlere tesadüf eder. Kadıköy ve Adalar'ın henüz meşhur olmadığı bu yıllarda İstanbullular kışları Suriçi ve Beyoğlu'nda, yazları Boğaziçi'nde geçirdiğinden kirada bir ev bulmak neredeyse imkânsız hâle gelmiştir. Cevdet Paşa, o yıllarda Boğaziçi'nin Bebek ve Büyükdere koylarındaki mehtap sefalarını bilhassa hatırlar ve İstanbul'da böylesine "zevk u safa rüzgârları esmeye başlayınca kulları da bütün bütün hariç kalamadım.” diyerek devrin modasına uyduğunu itiraf eder. (Cevdet Paşa 1980: 6-8) Ahmet Hamdi Tanpınar da Cevdet Paşa'nın bıraktığı yerden İstanbul'da değişen hayatı anlatırken Müslümanların sadece yazları tanık olabildiği ecnebi kıyafet ve âdetlere, Beyoğlu'nda kışları da tesadüf ettiklerini söyler. Batı hayat tarzı, taklit ve moda ile bu yıllarda Müslüman İstanbul'un sokaklarında kendisine kalıcı bir yer edinmeye başlar. Avrupa işi mobilyalar, makyaj malzemeleri, kıyafetler Müslümanların daha sık kullandığı ve talep ettiği unsurlar olur. 
Büyükdere'de kotra yarışları, haremlerde piyano dersleri vermek isteyen ecnebi bir kadının ilanı gündelik hayatın bir parçası haline gelir. (Tanpınar 2012: 139140) Yenileşme Mustafa Reşid Paşa'nın devlet ve fikir adamı hususiyetiyle inşa edilirken, bu fikrin göze hitabını Sultan Abdülmecid sağlamıştır. O, Tanpınar'a göre, Fransızca okuyup konuşan, piyano çalan, sarayın hemen yanına küçük bir tiyatro kurduran, Avrupalı sanatçılara saray orkestrası tertip ettiren bir padişahtır. Ancak bütün bu yenilikler karşısında ölüm döşeğindeki karısının yüzünü hususi doktoruna örtüsüyle göstermek zorunda kalacak kadar kamuoyu bask1sından çekinir. (Tanpınar 2012: 140) Bu sebepten Abdülmecid devri Avrupalı11ğı bazı sahalarda "millî ve mahallî hayata vurulmuş küçük bir frenk cilası"dır. En nihayetinde "hayatın yaratıcı pınarı kurumuştu"r. (Tanpınar 2012: 142) Meyhanelerde dahi 1880'lere kadar masada değil, iskemleler üzerine konan bakır sini sofralarda yenilen içilen bir kültür vardır. Bu ikilik, Tanzimat devrinde sanat, siyaset, toplum, din, kültür üzerinden günümüze kadar devam edecek bir cepheleşmeyi haber verir. Malik Aksel bu sebepten olsa gerek Şehzadebaşı'nın bir tezatlar yeri olduğunu söyler. "Bir taraftan vaizler tiyatroya gitmeyi günah sayarken bir taraftan da meddahlar taklitler yaparak: - Tiyatroya gidende, çılbah kızlar görende, geğre suyu (rakı) içinde, kapan da kaçan mı cenneti? diyorlar.” (Aksel 2011: 11) diyerek din üzerinden geleneğin, meddah etrafında aktüelin çatışmasını gösterir. Ancak 19. asır sahne sanatları söz konusu olduğunda batılı tiyatroyla geleneksel seyirlik Türk tiyatrosu bir arada yaşamaya devam eder.

Türk tiyatrosu yukarıda sözü edilen mali sıkıntılardan, İstanbul'daki sosyal yapının değişmesinden ve hem batılı bir hayatı teklif edip hem de dini muhayyileyi ve kamuoyu tehdidini görmezden gelemeyen padişahlardan bağımsız değildir. Tiyatro, Tanzimat yıllarında batıdan ithal edilen edebi türlerin en eskisidir. Tanpınar, modernleşme portresini tamamlarken "Gümrükten geçen her şey Müslümanlaşıyordu." (Tanpınar 2004: 126) der. Malik Aksel de devrin meşhur komikleri Abdi ile Kel Hasan'ın başlarında sarık teravihe gittiklerini, namazdan sonra tiyatroya koştuklarını söyler: "Bunlar oyun seyretmeye değil, oyun oynamaya koşuyorlardı. Bununla beraber arkadan cemaat da onları takipten geri kalmiyordu." (Aksel 2011: 4)

Batı tarzı Türk edebiyatı Şinasi'nin Şair Evlenmesi (1859) oyunu ile baş- 
lar. Batılılaşmanın hâkim türü roman kabul edilse de edebiyatta bu yolu tiyatro açmıştır. Şinasi, Namık Kemal, Ahmed Midhat Efendi, Şemseddin Sami gibi Tanzimat'ın ilk kuşak sanatçıları yeni bir toplum inşasını tiyatro vasıtasıyla mümkün kılmaya çalışmışlardır. Romandan daha tez canlı bir biçimde tiyatroya sığınmalarının birtakım gerekçeleri vardır ancak bu çalışma içerisinde Türk edebiyatçılarının kitap formunda yayımladıkları metinlerden daha çok tiyatronun icra edilen bir sanat olması merkeze alınarak kişi ve kurumlardan bahsedilecektir. Güllü Agop'un Osmanlı Tiyatrosu'ndan Meşrutiyet'in hemen öncesine kadar Türk tiyatrosunun kişileri, toplulukları etrafında kumpanyalar, kantolar, kahvehane gösterileri, meddah, ortaoyunu ve Karagöz'den söz edilecektir. Yaklaşık 19. asrın sonundan 20. asrın ilk çeyreğine kadar geçen süreyi içine alan bu dönem İstanbul folkloru dendiğinde göz ardı edilemeyecek isimlerden Sermet Muhtar Alus'un yazdıkları etrafında değerlendirilecektir. Türk tiyatro tarihi Alus'un yazdıkları incelenmeden eksik kalacak bir tarihtir.

Sermet Muhtar Alus, (1887-1952) ömrünü İstanbul'a adamış bir muharrir ve romancıdır. Yazdıklarının hemen tamamı tecrübelerine dayandığından elimizdeki yazı ve kitapları hatırat niteliği taşır. Özel zamanların kayda alındığı bu metinlerde bir tiyatro tarihçisinden çok sivil bir edebiyatçı ve yazar kimliği öne çıkar. Belki buna ilave olarak söylenebilir ki Alus, J. Habermas'ın birtakım sosyal mekânlar üzerine inşa ettiği teorisini geçerli kılmaz. Bu teoriye göre hamam, mabet, tekke, kahvehane gibi kamusal mekânlar kamuoyu fikrinin biçimlendiği demokratik kamusal alanlardır. Ancak Osmanlı toplumunda söz konusu mekânlar kısmen bu türden bir işleve sahip olsalar da Alus bunu yazmayı tercih etmez. Onda, tiyatro ya da kahvehanelerde icra edilen Karagöz ve meddah gösterileri, siyasî bir bilince dönüşmez. Oysa Karagöz gösterilerindeki siyasi hiciv ve kamuoyu oluşturma çabaları bilinen bir hakikattir. 1800'lerin sonunda Kıbrıslı Mehmed Paşa'nın karıştığı bir yolsuzluğu anlatan Karagöz gösterisinden sonra oyunlar yasaklanmıştır. Metin And, bu oyunların basit, karnavalesk bir yapıda olduğunu söyler. Toplumun her tabakasından insanın bir arada eğlendiği bu mekânlarda siyasi bir tepkinin oluşması da beklenemez.

Sermet Muhtar Alus, İstanbul'a dair yazılarını düzenli olarak ileri yaşlarında, 1930'lardan sonra kaleme alsa da onun ilk gençliğinden beri kayıt tuttu- 
ğu yazdıklarından anlaşılır. Köşe yazılarındaki birtakım ifadeler bunu gösterir. Çünkü, ciltler dolusu bir hacmi ardında bırakan Alus'un bunları günlük bir gazete için bir anda hatırlaması mümkün değildir. Yer, zaman, hadise ve kişilere dair hatırladıkları bir arşive dayanıyor olmalıdır. Gençlik yıllarında disiplin ve bilinç içerisinde olduğu, sadece gazeteden maişetini karşılamak için yazmadığ 1srarla İstanbul'u söz konusu etmek istediği görülür. Yazarı bu 1srar ve disipline sevk eden gerekçeler vardır. Her şeyden önce 1930'lar, İstanbul'un sıradanlaştırıldığg ve terk edildiği yıllardır. Ankara'nın başkent olması, İstanbul'un bütün mirasını sarsmıştır. Elçilikler Ankara’ya taşınmış, devletçi politikalar ekonomide millîliği öncelemiş bu da yabancı servet sahiplerinin memleketten uzaklaşmasına sebep olmuştur. Onlarla birlikte İstanbul'un çok kültürlü kimliği de parçalanmıştır. Bu ortamda yazılarını kaleme alan Alus'un 1srarla İstanbul'u anlatmasının ardında yatan neden yeni rejim ve başkent karşısında yok edilen bir kültürün kayıt tutucusu olma refleksi ve iradesidir. Çünkü on yıllarca her gün gazete sütunlarında anlatılan bu dünya Meşrutiyet’ten sonra kademeli bir biçimde hayattan çekilmiştir. Kültür yok olmuş, değerler değişmiş, toplu eğlenmeler şahsileşmiştir. Ekim devriminde Bolşeviklerin baskısından kaçan Çar yanlısı Beyaz Rusların İstanbul'a göç etmeleriyle kantocular yerlerini varyetecilere bırakmıştır. Artık sahnede dans eden kadın, bir geleneğin içerisinden değil sadece bedeniyle kimlik sahibi olmaya ve hayatını kazanmaya çalışan bir profesyoneldir. Alus'un cümle hacmine çeviremediği bu eskiye dönüşü Tanpınar "Bizi onlara doğru çeken bıraktıkları boşluğun kendisidir." diyerek tarif eder. (Tanpınar 2004: 207) Sermet Muhtar, bir devrin büyük meşhurlarının yalnızlık içerisinde ölmelerine tepki duymuştur. Onları yeniden var etmek arzusuyla yazdığg ortadadır. Öte taraftan M. Foucault'nun kendi içlerinde bağdaşmaz birçok mekâna bir aradalık kazandıran heterotopya söylemi Alus’un dünyasını tarif eder. Alus, kahvehaneyi, sayfiyeyi, tiyatroyu, yenidünyayı tek bir mekâna indirger. Eğlence esastır. Cinsellik, kahve, okuma enstrümanları, müzik, kumar, uyuşturucu bir aradadır. Söz gelimi Tanzimat'la birlikte gazete tekil okuru var etmiş, modern okullar cemaatten bağımsız kitaba dönük bir başına öğrenmeyi getirmiştir. Abdülaziz devrinde kahvehanelerde günlük gazetelerin bulunması orada bilinçle yer alan okur tipini yaratmıştır. Bu özelliği ile kahvehaneler Tan- 
zimat yıllarında geleneğin bir parçası olmaktan uzaklaşmıştır. Ancak eğlence söz konusu olduğunda toplum, cemaat yapısını muhafaza etmiştir. Kahvehane ya da herhangi bir eğlence kurumu bireysel kararla tercih edilse de var olan eğlence kalabalıkla olur. Bu da birey ve cemaatin bir heterotopya etrafinda buluşmasını sağlar. Nebi Özdemir de Türklerin toplu eğlenmeye eğilimli olduğunu, topluluk bilincinin baskın olduğu Türkiye'de kişinin tek başına eğlenmesinin normal bir davranış olarak nitelendirilmediğini söyler. (Özdemir 2005: 285) Bunun devamında kahvehanelerin varlık sebebi klasik Osmanlı toplumunun işlevsel mekânlarından farklıdır. Ekrem Işın'a göre, 16. asra kadar Osmanlı hayat tarzının sınırları, görev ahlakıyla çizilmiş cami, ticarethane ve konut ile çevrilidir. Mahalle kahveleri ise temel ihtiyaçların dışında, sınırları toplumsal görev ahlakıyla çizilmemiş bir hayat tarzını Osmanlı insanına sunar. (Işın 2001: 27)

Tanzimat öncesinde eğlence muhafazakâr bir formdadır. Eğlenen ve eğlendirenin hemcins olduğu cemiyetler ev, köşk gibi daha dar ve kamuya kapalı mekânlardır. Geleneksel Osmanlı hayatında durum bu iken, yabancı elçilik binalarında tiyatro gösterimleri çok erken tarihlerde başlamıştır. Rumların apukurya şenlikleri Osmanlıların müzikli, danslı eğlencelere aşinalık kazanmasını sağlamıştır. Yine ticaret için İstanbul limanına gelenlerin meyhane eğlenceleri, helva sohbetlerinin tertip edildiği kış gecesi oturmaları devrin eğlencelerine numunedir.

Sermet Muhtar Alus, içine doğduğu kültürün Meşrutiyet’ten sonra silinmeye başladığını, Cumhuriyet'le birlikte bunun tamamen ortadan kalktı̆̆ının bilincinde bir yazardır. Ancak bu bilinç onu mekânların ve tiyatro sanatının politik bir yorumuna taşımaz. Bu açıdan J. Habermas'ın siyasi, protest bir kümelenme gördüğü mekânlardan çok M. Foucault'nun heterotopya dediği mekânları kaleme alarak Osmanlı toplumunun son asırdaki bütün ses ve renklerini metnine taşır. Yine de Alus'un kahvehanelerinde uyuşturucu, oğlancılık, müstehcen hikâyelerin çocuklar karşısında mimik ve el hareketleriyle anlatılmasının söz konusu edilmediği söylenmelidir. Bu girişin ardından Güllü Agop'un Osmanlı Tiyatrosu ile elde ettiği imtiyazdan Meşrutiyet öncesinde son büyük hareketliliğini yaşayan Direklerarası'na Türk tiyatrosunun modern ve geleneksel dünyası Alus'un tanıklıkları ile anlatılacaktır. 


\section{Batı Tarzı Türk Tiyatrosu}

Gedikpaşa'da Kurulan Osmanlı Tiyatrosu: Sermet Muhtar Alus'un yazılarında Batılı anlamda Türk tiyatrosunun kurucusu kabul edilen Güllü Agop özel bir yer tutar. 1859 'da Soulier ${ }^{1}$ sirki için Gedikpaşa'da inşa olunan yapıyı 1867 'de yönetimine alan Agop, tiyatrosunu burada Osmanlı Tiyatrosu adiyla kurmuştur. Alus, edebiyatçılardan bir zâtın gelişigüzel tercümelerin liyakatsizliğine tepki göstererek Kocaya Tuzak komedisini tercüme ile Agop Vartovyan'a gönderdiğini, bu hadiseden bir yıl sonra da Gedikpaşa'da Osmanlı Tiyatrosu'nun temelinin atıldığını yazar. Agop Efendi'nin, Güllü Agop olarak anılmaya başlaması da bu tarihten sonradır. ${ }^{2}$

Gedikpaşa'da, Çarşıkapısı'ndan Kumkapı'ya inen yokuşun solunda, o zamanlar Azak Sineması olan mahalde, Soulier isminde bir Fransız, vaktiyle bir cambazhane işletmiştir. Kimi kaynaklarda sirk olarak geçen bu mekânın patron tarafından terk edilmesi, bazı Türk aydınlarını harekete geçirmiş ve mekân satın alınarak tadilatla tiyatro hâline sokulmuştur. Adına da Osmanlı Tiyatrosu denmiştir. Osmanlı Tiyatrosu'nda ilk temsil 1867 yılı ramazanında Leyla ile Mecnun oyunuyla olmuştur. Sermet Muhtar, tiyatroya edebî bir heyetin nezaret ettiğini, Namık Kemal, Âli Bey, Recaizade Ekrem, Ebuzziya Tevfik, Şemseddin Sami, Manastırlı Rifat, Hasan Bedreddin, Ahmed Midhat Efendi'nin piyeslerinin burada sahnelendiğini belirtir.

Güllü Agop, Sultan Abdülaziz'in oğlu Yusuf İzzeddin Efendi’nin düğününde İstanbullulara Türkçe temsiller sunmuş, özellikle Zor Nikahı'ndaki performansıyla Âli Paşa'nın ilgisini çekmiştir. Sadrazam Âli Paşa'nın tavassutuyla 1870'den 1880'e suflörle Türkçe oyun oynamak fermanı Sultan Abdülaziz'den Güllü Agop'a verilmiştir. Yapılan anlaşma gereğince tiyatro, ramazan aylarında sadece Türkçe oyun sahneleyebilecektir. (And 1976: 42-43) Türkleri tiyatroya çekebilmek için hızla çalışmalara başlayan Agop Efendi, seyircinin çabuk bağ kurabileceği hikâyeleri sahneye taşımıştır. Leyla ile Mecnun'u tiyatro eseri hâline getirmesindeki amaç budur. (Koçak 2011: 269) Ancak bu tekel, diğer toplulukların imkânını kısıtlamış, onları başka yollara sevk etmiştir. Dikran Çuhacıyan

1 Soulier hakkında daha geniş bilgi için bakınız: Metin And, Osmanlı Tiyatrosu, s. 20-21.

2 Alus, Ermenci'de “vart” kelimesinin gül manasına geldiğini, "vatrov"un da güllü demek olduğunu hatırlatır. 
müzikli oyun oynayarak bu tekeli kırmayı denemiş, Agop'un tekeline takılan topluluklar İstanbul dışına gitmek zorunda kalmışlardır. Bursa'nın Türk tiyatro tarihinde önemli bir merkez hâline gelmesinin ardında bu tekelin tahakkümü yatar. ${ }^{3}$ Güllü Agop'un tekeline esaslı darbe Kavuklu Hamdi'nin Aksaray'da Hayalhâne-i Osmanî Kumpanyasını kurmasıdır. Rus harbinin başlamasıyla Güllü Agop'un kadrosu Edirne' de Ruslara destek gösterimleri yapmış, bu olay Agop'un elini zayıflatmıştır. Ermeni olaylarının da bu dönemde belirmesiyle tekel gücünü yitirmiştir. Güllü Agop saraya çağrılmış, Muzika-yı Hümayun’a getirilmiştir. İslam’1 kabul eden Güllü Agop, Yakup Efendi adını almıştır.

Güllü Agop’un tekeli Türkçe komedya, dram, trajedi, vodvil gibi dramatik türlerdir. Müzikli oyunlar tekele dâhil değildir. Osmanlı Tiyatrosu'nun repertuarı devrin edebiyat anlayışına uygun bir biçimde Fransız tiyatro metinlerinden adaptelerle kurulmuştur. Moliere'den Hugo’ya klasik eserler, dramlar; Montepin'den Jules Marie'den cinaî melodramlar, Türkçe telif facialar, Avrupa opera ve opera komikleri, yeni operetlerin yanında senede birkaç defa Ermenice piyesler oynanmıştır. Aktris ve aktörleri arasında Yeranuhi Karakaşyan, Verkine Karakaşyan, Nivart, Araksi, Bedros Magakiyan, Mardiros Minakyan, Atamyan, Papazyan, Tospatyan, Narliyan, Çaprast, Sisak, Sanikciyan, Matosyan gibi Ermenilerin yanısıra, Ahmed Necip, Hamid, ressam Münif Fehim'in babası Fehim Efendi gibi Türk sanatçılar da bulunur.

$\mathrm{Bu}$ imtiyaz son bulunca Direklerarası yeni sahnelerin merkezi olmuştur. Mardiros Minakyan ve Tomas Fasulyacıyan'ın Osmanlı Dram Kumpanyası, Eğlencehâne-i Osmanî Kumpanyası, Handehâne-i Osmanî Kumpanyası Alus’un sözünü ettiği ancak yakın isimlerle kurulan sair topluluklar Direklerarası etrafinda Türk tiyatrosunun yeni çehresini oluşturmuşlardır. Bu topluluklarda Ermeni ve Türk oyuncular bir arada çalışmışlar, ortaoyunundan gelen Abdürrezzak Efendi, Kavuklu Hamdi, Komik Şevki, Kel Hasan, Küçük İsmail burada sahneye çıkmışlardır.

Gedikpaşa'daki Osmanlı Tiyatrosu, Güllü Agop’un saraya alınmasından

\footnotetext{
3 Sermet Muhtar Alus'un yazdıklarında ise daha farklı bir durum vardır. Buna göre, Gedikpaşa Tiyatrosu'nun “ortada kalan” aktörleri ve sanatçıları, rejisör Fasulyacıyan'la birlikte Bursa'ya gitmişlerdir. Bursa Valisi Ahmed Vefik Paşa'nın himayesiyle Moliere'den adapte ve tercüme ettikleri komedileri bu şehirde sahneleme imkânı bulmuşlardır. Alus, o sıralarda, yani 1883'te babasının da Bursa'da bulunduğunu, kumpanyanın babasının Muhaceret adlı beș perdelik oyununu temsil ettiğini söyler. Üç yıl sonra, Ahmed Vefik Paşa'nın Bursa'dan İstanbul'a dönmesiyle tiyatro ve aktörler dağılmışlardır. Alus, bu esnada, Gedikpaşa'daki aktrislerden Mınakyan'ın yine Osmanlı Tiyatrosu adıyla bir kumpanya kurup direktörlüğünü üstlendiğini yazar. (Alus 1941: 4)
} 
sonra bir süre Fasulyeciyan tarafından devam ettirilmiştir. Fasulyeciyan, Direklerarası ile rekabet edemeyince Gedikpaşa'yı dağıtıp Selanik'e turneye gitmiştir. Buranın kapılarını açmak ilk Türk aktörlerden Ahmed Fehim’e kalmıştır. Ahmed Fehim kendi döneminde Ahmed Midhat Efendi'nin Çengi ve Çerkes Özdenler, Şemseddin Sami’nin Besa oyunlarını sahnelemiştir. Ancak Ahmed Midhat Efendi'nin Çerkes Özdenleri eserinin büyük alkış aldığı sıralarda "Bu oyun Çerkeslerde istiklâl fikrinin uyanmasına sebep olacak. Muhtelif anasır ve tebaa arasında fitne ve fesad çıkaracak" jurnaliyle oyun yasaklanıış, 1882'de, bir gece içerisinde belediye amelelerine tiyatro binası yıktırılmıştır. Midhat Efendi tutuklanmış, devrin ilginç bir baskılama yöntemi olarak saraya alınmıştır. Dahası 1908'e kadar Türk edebiyatında telif oyun yazılamamış, yazılsa da sahnelenememiştir. Üretilen metin olmaması batılı tiyatro disiplininin gelişmesini ve dolaylı bir biçimde Türk oyuncuların yetişmesini engellemiştir. Darülbedayi günlerinde tiyatronun gidermeye çalıştığı eksiklerden biri yerli hikâyelerin Ermeni ve Rum oyuncular dilinde kırık bir Türkçe ile sahnelenmesinin önüne geçecek Türk oyuncu bulmak olmuştur.

Mınakyan'ın Osmanlı Tiyatrosu: Gedikpaşa'daki Güllü Agop'un tiyatrosu padişahın iradesiyle bir gecede yakılmış ve yıkılmıştır. Mınakyan kumpanyas1 da "Güllü Agop'un bir istihalesi”" olarak hayat bulmuş ancak Alus'un ifadesiyle o kuvvete erişememiştir. Yine de devrin yüksek ve münevver tabakasının ilgisini çekmiştir. T1bbiye, Harbiye, Mühendishane, Hendese-i Mülkiye talebeleri, “efendiden adamlar" izleyicileri arasındadır. (Alus 2005: 50)

Mınakyan'ın repertuvarı oldukça geniştir. Devrin tabiriyle "hissî”' komediler oynasa da ekseriyetle cinaî melodramları sahnelemiştir. Olaylar Paris'in kibar kâşanelerinde, Seine Nehri civarındaki büyük şatolarda geçer. Millî piyeslerin "şiddetle yasak" olduğu bu devirde, şahıslar kıyafetlerinden hemen tanınır. Kırmızı saçlı Toni Grok’ın sekiz kişiden oluşan ve diğer orkestraların dağınıklığını göstermeyen profesyonel orkestrası, oyun başlamadan önce parçalar çalar. (Alus 1950c: 104)

$\mathrm{Bu}$ oyunlarda her rolün sahibi muayyendir. Minakyan Efendi, daima müşfik, aile adamı, çocuklarına düşkün bir baba rolüne çıkar. Vaktiyle Bursa'da Fasulyacıyan'ın aktörlerinden, Vali Ahmed Vefik Paşa'nın yetiştirdiği Holas, 
Türkçeyi doğru kullanan, aksanına Ermeni şivesi karıştırmayan, sözlerine "ka, mega, zo" ifadelerini katmayan bir oyuncudur. Alicenap, babacan rollerinde görülür. "Gedikli Jön prömiye” Binemeciyan da Alus'un kaleminden aktarılan sanatçılardandır. Hoppa hanımların göz bebeği olan Binemeciyan, La Dame aux camélias' da Arman Düval'i, Kontes Sara'da Piyer Sevrak'1, Bir Fakir Delikanllnın Hikâyesi'nde Maksim'i oynarken, kafesler ardında kadınlar gözyaşlarını tutamazlar. Aleksanyan ise, bütün oyunların müfsit, hain, kanlı kişisidir. O devirde İstanbullular içinde ondan başka bıyığını tıraş eden olmazmış. Şahinyan ise ikinci jön olarak nadiren Binemeciyan'ın yerini alan sanatçıdır. Diğer oyuncular Ahbar Çobanyan, Aleksanyan, Çaprastciyan'dır. Türk tiyatrosunun önemli oyuncularından Kınar Hanım, Mınakyan kumpanyasının en hareketli yıllarını görememiş olsa da bu kumpanya ile anılır. Alus, "Mini mini vücuduyla Fru Fru'daki hali hâlâ gözümün önündedir.” diyerek Kınar Hanım’1 anmadan edemez. (Alus 2005: 55)

Mardiros Mınakyan, 1839'da Balat'ta doğmuş bir terzi oğludur. Hasköy'deki Nersesyan Ermeni mektebinde muallimken, mektebin tiyatro temsillerine katılmıştır. Beyoğlu'nda Said Paşa geçidinin arsasında bulunan ve 1870 'teki büyük yangında yok olan Hoca Naum Tiyatrosunda Ermenice oyunlarda rol almıştır. 1885 'te Osmanlı Tiyatrosu'nu kurmuş, oyun çevirmenliği, rejisörlük ve yaklaşık yirmi beş yıl oyunculuk yapmıştır. O tarihten 1908'e kadar her ramazan Direklerarası'nda, yazları İcadiye'de, Boğaziçi'nde, Bakırköy'de aralıksız oyunlarına devam etmiş̧ir. Sermet Muhtar, repertuvarındaki hissî dramların, cinaî melodramların çoğunu bizzat kendisinin tercüme ettiğini, bunlara bir perdelik Gülünçlü Komedi eklediğini söyler. Meşrutiyet'in ilanıyla birlikte tiyatroya ara ara devam etmiş, 1912'de sahneye çıkışının 50. yılı dolayısıyla jübilesi yapılmış, göğsüne Maarif Nişanı takılmıştır. 1916 yılına kadar sahnede kalmış, 1920'de ölmüştür. ${ }^{4}$

Osmanlı Dram Kumpanyası: Sermet Muhtar Alus, 1947 yılında bir gün Bayezid meydanında eline Türkçe ve Ermenice hazırlanmış bir tiyatro ilanının tutuşturulduğunu söyler. Bu ilan Alus'a, bir vakitlerin Osmanlı Dram Kumpanyasını kuran Mınakyan’ı hatırlatır. Şimdi onun halefleri, kırk yıl sonra

4 Mınakyan’ın biyografisi hakkında bir başka yazı: Alus, Sermet Muhtar, "Manakyanın Meşhur Aktörü Binemeciyan”, Akşam, s. 4, 31 Ağustos 1941. 
“icra-yı lu‘biyata” başlamışlardır. (Alus 1947b: 4) Bunu da dedeleri Güllü Agop'un Fasulyacıyan'ın mekânında, Gedikpaşa tiyatrosu arsasındaki Azak Bahçesi'nde yaparlar. İlanda “Türk Dram Tiyatrosu: Mınakyan'ın Temsilleri. Rejisör O. Şahin.” yazar. Alus, “bu elebaşı”’nın eski aktör Ciciburun Şahinyan’ın oğlu olabileceğini tahmin eder. O akşamki oyunları da Demirhane Müdürü' dür. $\mathrm{Bu}$ piyesin baş aktrislerinden biri Bayan Nıvart'tır. Alus, onun yıllardan beri şanodan çekildiğini, Viktor Haçikyan'1 ise Halep’te bulunduğu yıllarda, Sabun Hanı'nda, Ayı Mehmed'in kumpanyasında, “pek körpe” çağlarında gördüğünü yazar. İlanın Ermenice kısmında biletlerin Gedikpaşa Caddesi’nde 71 Numaralı Bakkal Nubar Balıkçıyan’ın, Kapalıçarşı'da Yetvart Yeresyan’ın, Kadırga Caddesi'nde kunduracı Onnik Borsaliyan'ın dükkânlarında ve Azak Sineması gişesinde bulunabileceği yazıyordur.

Leonidas'ın Varyete Kumpanyası: 1903 kışının sonlarında aslen Yunanistanlı olan oyuncu Leonidas, Avrupa’yı dolaştıktan sonra İstanbul'a gelmiş, Konkordiya Tiyatrosu'nda “üç dört ay para kırmış”tır. Haftada bir Kuşdili'ndeki salaş tiyatroda sahneye çıkmıştır. Kuşdili'nin “gediklisi” Kel Hasan, cuma ve pazarları orada, hafta içinde de Mama, Libade, Göksu, Bakırköy gibi yerlerde tuluat oynadığından salı günleri tiyatrosunu Leonidas'a kiralamıştır. (Alus 1950d: 5)

Galata Tiyatroları: Galata ve Pera'daki eğlenceler, Tanzimat'la hayatımıza giren mesire eğlencelerini dahi gölgede bırakmış, onların birkaç on yıl içerisinde eskimesine sebep olmuştur. Burada kurulan tiyatrolar salaş yapılar biçiminde tarif edilir. Liman amelelerinin ve gemi mürettebatının müdavimi olduğu, müzikli mekânlardır. Baloz adıyla meşhurlardır. Buralarda daha çok Rum, Ermeni, İtalyan sanatçılar gösteri yapsa da zaman zaman tuluat ustalarından Abdürrezzak Abdi, Amerika Tiyatrosunda, Kavuklu Hamdi, Avrupa Tiyatrosunda çıkmıştır. Türk tiyatro tarihi açısından en meşhur Galata tiyatrosu Pirinççi Gazinosu'dur. Fasulyeciyan, Güllü Agop'un tiyatrosundan ayrıldıktan sonra kendi başına faaliyet yürütmek istemiş ancak tekele takılmıştır. Bunun üzerine tekel kapsamında bulunmayan Ortaoyununu sahneye taşıyarak suflörsüz tiyatroyu başlatmıştır. Kavuklu Hamdi’yle anlaşarak daha önce görülmemiş ve gelecekte tuluat tiyatrosu adıyla anılacak yeni bir tiyatro icrasını hayata geçirmiştir. 
(Pekman 2011: 133) Bu sanatı ilk icra eden Kavuklu Hamdi, popülerleştirenler ise Abdürrezzak ve Kel Hasan'dır.

Galata bölgesinde kafe şantan denilen, dansözlerin ve şantözlerin sahne aldığı barlar da vardır. Konkordiya bu barlar arasında Kristal'le birlikte en çok bilinenidir. Büyükçe bir bina olmasından dolayı yabancı trupların, operetlerin, varyete kumpanyalarının tercihi olmuştur. Alus'un ilk gençliğinde Konkordiya'nın yerine Saint Antoine Kilisesi yapılmış, Kristal ise kapanmıştır. (Alus 1947: 4)

Kantolar: Kanto, İtalyanca nağme anlamına gelen canto kelimesinden dilimize geçmiştir. Güllü Agop'un tekelinden kurtulmaya çalışanların icadı tuluat tiyatrosu ile batı tarzı tiyatro arasında bir noktada durur. Toplumun çağdaşlaşma istekleriyle değerlerinin değiştiği bir dönemde ortaya çıkmıştır. Kantoya çıkan kadınların ses, dans ve bedenlerini sergiledikleri kantolar cinsel kültürün değişmesine katkıda bulunmuş, alt kültür müziğidir. (Pekman 2011: 50) Kanto, tiyatrolarda komik-i şehir sahneye gelmeden önce icra edilen bir sanattır. Osmanlı dönemi tiyatrosu, sadece metne dayalı ya da doğaçlama oyunların sergilendiği bir faaliyet değildir. Kompleks bir eğlence hâkimdir. Buna bağlı olarak Gedikpaşa tiyatrosunun bahçesinde alaturka müzik yapan bir gazinonun olduğu hatırlanmalıdır. Kantocuların sahneden inmesinden sonra komik-i şehir sahneye çıkar, müzik ve dansa dönük seyir, yerini zekâ dolu mizaha bırakır. (Koçak 2011: 232) Refik Ahmet Sevengil de "Tuluat tiyatrolarında oyun ve konu önemsenmezdi. Önemli olan halkın bir buçuk iki saat ilgisini çekmekti.” diyerek oyun dışında kantoların söylendiğini, perdenin bozuk düzen bir orkestranın gürültüleri ile açıldığını, sahnenin bir köşesinden kantocu kızların neredeyse çıplak bir hâlde tüller içinde ortaya geldiğini yazar. Ona göre kanto hiçbir estetik değeri olmayan bir beste, güfte ve danstan ibarettir. (Sevengil 2014: 243-244)

Sermet Muhtar, eski kantocuların onda dokuzunun "iri kıyım, etli butlu" olduklarını söyler. (Alus 1948d: 2) Eski İstanbul'da kantocuların gözde olanlarının çok gerisinde kalan acemiler de vardır. Lakabı Kemankaşıı olan Viktor, kişizade bir mirasyediye vararak kendisini unutturmuş, bıldırcına benzetilen Teraza, kabasakal Çerkez Mehmed Paşa’nın ortanca oğluyla “kapanmış”, Eftimya ise önceden çalıştığı balozu daha kârlı bularak Galata’ya dönmüştür. Büyük 
Amelya, şişmanca olduğundan dans edemez ancak muhafaza etmeyi bildiği güzel sesiyle şarkılar söylermiş.

Gözde kantoculardan ilki, çekemeyenlerin karanlık ağızlı diyerek "kulp taktıkları" Küçük Virjini'dir. Kibar ve çıtıpıtı olarak tarif edilir: "Kadınlar meclisinde hatır için şöyle oyuna kalkıveren bir ev hanımı halliydi." Virjini sahneye elinde bir güvercinle çıkar, Güvercin kantosuna nazlı nazlı başlarmış. Kemancı Yorgi'yle evlenmiştir.

Devrin meşhur kantocularından bir diğeri Küçük Eleni'dir. Alus, Eleni'nin önce Abdürrezzak'ın Hanende-i Osmanî’sinde, Abdi saraya alındıktan sonra da Küçük İsmail'le Şeyh Hakkı'nın kumpanyasında tek başına kantoculuk yaptığını söyler. (Alus 1948e: 2) Eleni, ablak yüzlü, kısa saçlı, akça pakça diye tarif edilir. Tepesinde beyaz tüyden bir sorguçla, kovalanan keklik gibi sahneye çıkar, mosmor kesilene kadar şarkı söyler, ancak söyledikleri hiç anlaşılmazmış. Rumca sözleri olan Papuç kantosunda, gemici dansında, oyun sonunda düğün dernek yapılırken çalınan davul zurnada da nefes almadan boyuna zıplarmış.

İstanbul'un kantocularından bir diğeri Gemela'dır. Tatavlalı Fotini yıllarca Suriye şehirlerinde dolaştıktan, dilber zamanlarını orada geçirdikten, sıskalaştıktan sonra İstanbul'a dönüp Gemela ismiyle Mınakyan'ın tiyatrosunda oynamaya başlamıştır.

Küçük Amelya ise, tatarımsı, göz kapakları şiş̧̧e, şişman, bastıbacak, Çince konuşuyor gibidir. Uzun boyunlu ve bacaklı, pandomimacıllktan yetişmiş, tuluatçılığı da iyi olan kocası Todori ile Şamram ya da Peruz'un "galiba" teyzesinin kızı, tiyatrocu Şevki'nin karısıdır. Şanoda dürüst konuşan Şamram, kelimelerin hakkını verir, Bozacı, Turşucu gibi komik düettoların da sahibidir. Devrin meşhur kantocularından Şamram, kantolarını kendisi yazmıştır. (Es 2010: 50)

Sermet Muhtar, Peruz'un kantocuların kadinnesi olduğunu söyler. Çatıkça kaşları, balıketli vücuduyla zamanında ortalığı kasıp kavuşmuş, Alus'un çocukluk yıllarında “kartlaşmış”tır. Kel Hasan'ın onu Heybeli adasına benzetmesi meşhurdur.

Peruz: Bağlarbaşı'nda "Yuma, ah yuma seydi” nidalarıyla Arapça kantoya çıkan Peruz, 1940'ların sonunda yaşı ilerlemiş ancak kantocular arasında saygın bir yerdedir. Delikanlılar için kocakarı, hanımlar için dağların gelin anası Peruz 
"gün görmüş eski kurtlar"ın nazarında cazibesini koruyan bir figürdür. (Alus 1934c: 10) 1910'ların sonunda Mama mesiresinde Şevki'nin kumpanyasında sahneye çıkan Peruz, Güllü Agop'un, Fasulyacıyan'ın zamanlarında, bale heyetlerinde, alafranga tarzda şantözlerin olduğu ancak kantoların olmadığı sıralarda, kantocuların piri kabul edilmiştir. Bir zaman Direklerarası'nda Mehmed'in gazinosundan müdevver binada, Sahne-i Âlem'i kurmuştur. Onun âşılarının sayısı saçının telleri kadardır. (Aksel 2011: 8)

Beşiktaşlı Sofi: 1900'lerin kadın hanendeleri arasında Nasib Hanım, Topal Sıdıka Hanım, Hatice Hanım'ın adları geçse de devrin daha eski hanendesi Beşiktaşlı Sofi'dir. (Alus 1947ç: 4) Bu zanaatı icra eden başka Yahudi ve Hıristiyanlar olmasına rağmen Sofi, Abdülaziz devrinin sonlarında İstanbul'da emsalsiz kabul edilen bir hanendedir. O, Hasköylü Ester, Kuzguncuklu Roza ve Pangalt1l1 Hayganoş'u da geride bırakacak bir güce sahiptir. Doğma büyüme Beşiktaşlı'dır. Galata Kulesi'nin meydanındaki Pirinççi'nin gazinosunda saz takımında fasıllara katılmış, ortalığı yakıp kavurmuştur.

Alambra Tiyatrosu: 1950'lerin başında Galata rıhtımında, Denizyolları İdaresi'nin bulunduğu hanın yerinde çadır bezi ve pedavra tahtalarından Alambra adında bir tiyatro vardır. Alus, bu tiyatronun müşterileri arasında mavnacılar, kayıkçılar, ecnebi sefaret istasyonerlerinin tayfaları, miçoların ve kundura boyac1larının olduğunu söyler.

Amerika Tiyatrosu: Sermet Muhtar, Aya Nikola kilisesi hizasındaki Moskof Çalgısı adlı mekânı anlatırken buranın yanında o yıllarda çorap fabrikasına çevrilen bir tiyatrodan söz eder: Amerika Tiyatrosu. (Alus 1951b: 640) 1885’ten önce Büyük Amelya'nın kocası Sotiraki’nin işlettiği, başlıca oyuncularının Çingene Kosti, İstipsi Andon, Sarı Corci, Kel Refail, Püzant, Apik, Kantocu Büyük Amelya, Küçük Amelya, Çakır Marika'nın olduğu tiyatronun repertuvarında pondomimavari bir komedya, kantolar, tuluat veya dram bulunur. Abdurrahman Razzaki ve Kel Hasan da aptal oğlan rolünde burada sahneye çıkmıştır.

Avrupa Tiyatrosu: Avrupa Tiyatrosu, Galata'da bulunan ve kadrosunda Komik Arif, Kavuklu Hamdi, Büyük Asım, Küçük Asım, Şerbetçi Manoil, Davulcu Ahmed, sarhoş Peruz, meşhur Peruz, Kumkapılı Aranik, o zamanlar yenice ortaya çıkan Küçük Eleni'nin bulunduğu bir topluluktur. Kanto yazılarında sıkça 
karşımıza çıkan Peruz'a Alus burada da yer verir: "Peruz o çağlarda İstanbul'da bir tane; kaşının, gözünün, palûze vücudunun, edalı tavırlarının emsali yok; vurgunları gırla. Çeşmemeydanlı Aşir, Firuzağalı Rahmi, Tersaneli Makinist Ferhat, Bıçakçı Petri gibi belâlıları da sayısız." (Alus 1951b: 640)

\section{Geleneksel Türk Tiyatrosu}

Osmanlı Devleti'nin klasik döneminde şehzade düğünleri, “yenileşme döneminde" ise padişah kızlarının evlilik merasimleri, II. Abdülhamid'in cülus yıldönümlerinde tertip edilen donanma geceleri ramazanın dışında görülebilecek nadir eğlencelerdendir. Geleneksel Türk tiyatrosu dendiğinde de yaz mevsimlerinde mesire alanlarına kurulan seyyar sahnelerde oynanan ortaoyunu ve tuluat, ramazanlarda kahvehanelerde Karagöz icrası ve Direklerarası tiyatroları hatıra gelir.

Ortaoyunu: Tanzimat'tan önce Meydan-1 Sühan ya da Kol Oyunu denilen Ortaoyunu, İstanbul'a özgüdür ve Karagöz'le pek çok açıdan benzerlik gösterir. Metin And bu ilişkiyi şöyle yorumlar:

“Orta Oyunu, perde arkasında oynanan Karagöz'e karşı1lı, canlı oyuncularla oynanması bakımından ondan çok ayrı olmakla beraber, ruh, kişiler, oyunlar, güldürücülük, çatı bakımından öyle büyük benzerlikler gösterirler ki ikisi aynı zamanda çıkamayacağına göre, birinin ötekinden çıktığına inanmak zorunda kalırız, ama hangisinin önce geldiğine karar vermek güçtür.” (And 1962: 5)

Ortaoyunu, açık mekânlarda, iki paravana birkaç hasır iskemle dekoruyla çarçabuk kurulabildiği için şehrin her tarafina yayılmıştır. (Akbayar-Sakaoğlu 1999: 177) Bu yıllarda mesire alanları ve kır kahvehaneleri en rağbet gören mekânlar olmuştur. Malik Aksel'in, her şeyiyle bize ait gördüğü ortaoyununun (Aksel 2011: 29) en meşhur icracıları Abdürrezzak Abdi, Kavuklu Hamdi, Kel Hasan ve Küçük İsmail'dir.

Sermet Muhtar Alus'a göre, ortaoyunu millî tiyatromuzdur. (Alus 1950: 266) Eskiden ortaoyununa "Zuhuri kolu" ya da "Meydan oyunu" denmesinin sebebi, oyuncuların sahnede birer birer zuhur etmeleri, oyunun meydanda, ortada oynanmasıdır. Ortaoyunu Karagöz’ün canlı bir türüdür. Burada, Hacivat'ın yerine Pişekâr, Karagöz'ün yerine Kavuklu gelir. Hanım nine, boy boy zenneler, siyahî Şetaret Bacı, Razzakizâde Tarçın Bey, Tiryaki, Acem, Kayserili, Ak Arap, muha- 
cir, Laz, Arnavut, Kürt, Balama, Yahudi, matiz (sarhoş), Tuzsuz Bekir, aptal vs. şahıslar ortaoyununda tek tek sahne alırlar.

Ortaoyununda meydana, "yenidünya" denilen, paravanayı andıran, yanları bükülü tahta çıtalar yerleştirilir. Başından sonuna kadar, fasla zurna ile çifte nara eşlik eder. Meydana gelen her oyuncunun belirli bir havası bulunur. Sözgelimi, Pişekâr'ın bestesi segâh makamından, Kavuklununki hüseynîden, zennelerinki "Ey benim nazlı yârim severim kimse bilmez hâlim” güftesindendir. Oyuncuların her birinin bir türküsü olduğu da burada söylenir. Kayserili, "Gayseri g1zları, sırma gibi saçları"; Laz, "Hey tablalu tablalu, paraları turalu”; Kürt, "Karşıda Kürt evleri, yayılmış develeri”; Arnavut, "Tuna’da çırpar bezini pek sevdim Bulgar kızını" ile sahneye çıkar. Yahudi ise "Balat kapusundan yirdim içeri”yi söyler.

Sermet Muhtar Alus'a göre bu sanatın en önemli sanatçılarından biri Kavuklu Hamdi' dir.

Kavuklu Hamdi: "Eski Milli Tiyatromuz: Orta Oyunu"'nda, Kavuklu Hamdi’nin Çarşambaları Merdivenköyü civarındaki Mama'da, Pazartesi günleri Küçük Çamlıca yamacındaki Libade'de oynadığı, mesire alanlarını hıncahınç doldurduğu ifade edilir. Bu oyunlarda ağaçlar altında rütbeliler, kafes arkalarında kibar hanımefendiler hazır bulunurlar. Lu'biyat başlamadan önce kapı dışında Zurnacı Şişko Ahmed çığırtkanlık yapar, Kavuklu Hamdi'nin oğlu belediye kavaS1 Enver Efendi ${ }^{5}$ bir aşağı bir yukarı dolaşır.

Kavuklu Hamdi, doğma büyüme Eyüplü'dür. Sevimli, babacan bir "kıranta"dır. Tiyatroya, ortaoyununa mahalle arkadaşlarıyla bir araya gelerek, evlerden buldukları eşyalarla kendilerine kostümler yaparak başlamıştır. ${ }^{6}$ (Alus 1939: 10) "Bu anlattıklarımın hepsi rüyaymış meğerse" diyerek uydurduğu hikâyeleriyle ünlenmiştir.

Abdülaziz devrinde Silahtarağa'da oynamaya başlamıştır. Sultana, Kavuklu'nun oyunları haber verilmesi üzerine, Kavuklu ekibiyle beraber saraya çağrılmıştır. Ihlamur Köşkü meydanında oyunları seyreden padişah ferman çıka-

5 Alus'un dayızadesinin süt ninesi Berrak Hanım'ın kocasıdır.

6 Ahmed Rasim, Kavuklu'nun ortaoyununa nasıl başladığını kendisinden dinlemiştir. Alus, Ahmed Rasim'in duyduklarını aktarır: "Mahallede akranlarıyla bir araya toplanırlar. Kendi kadınannesinin eski feracesini alır, kimi kasaba yalvarıp yırtık peştemalını ister, kimi civar oyuncakçılardan bir havan koparır, bu da dedesinin kavuğunu aşırır; kıyafetleri düzerler, o vakit Meydanoyunu denilen oyuna girişirlermiş. Konu komşudan üşüşen üşüşene... Günün birinde arkadaşlarından birinin aklına esip: -Gelin, şu tahtaperdeli arsada oynayın. Ben kapıda durayım, şundan bundan on para, yirmi para alırsak pay ederiz! demiş. Tahtaperdeden içeri dalmışlar. Giriş o giriş..." (Alus 1948c: 2). 
rarak bu takıma Zuhuri Kolu denilmesini irade etmiştir. Abdülhamid'in tahta çıkışıyla birlikte Zuhuri Kolu, Şehremini Hastane Çayırı'nda, kale dışında Kavas’ın bağında oynamıştır.

Sermet Muhtar Kavuklu'nun gelinini kastederek “Gelini Berrak Hanım, yani belediye kavası Enver' in karısı, pek yakın bir akrabamızın evinde süt ninelik etmişti. Arada münasebet ve tanışıklık olduğu için Hamdi'nin hususiyetine dair epeyce malûmatım var.” diyerek Kavuklu'nun, para kazandığı devirlerde zendost, hovarda ve eli açık biri olduğunu söyler. Kayıklarla Kâğıthane'de, arabalarla Çırp1cı ve Veliefendi'de gününü gün eder. Kavuklu'nun Haliç’te geçirdiği bir kayık kazasından sonra denizde seyahat bir yana kıyılara dahi yanaşmaktan korktuğu anlatılır. Mama mesiresinin mevsimi başlayınca huzuru kaçar, adaklar adayarak, karş1 yakaya Üsküdar vapuruyla geçer, bütün yaz Eyüp'e uğramaz. Döndüğünde ise horoz kestiği nakledilir.

Kavuklu'nun en rağbette olduğu devir, Mama'da oynadığı yıllardır. Ortaoyunu başlamadan önce oyuncular, izleyiciler arasında hatırlı, ekâbirden kimselerin olup olmadığını tespit eder, buna göre oyunlarını yumuşatırlar. Sözgelimi içlerinde “Mer'iyyü'l-hâtır” misafirlerin olduğu oyunlarda Suriyeli veya Iraklı varsa baklavacı hacı baba, Arnavut varsa Bozacı Arnavut, Ak Arap varsa Bayrampaşalı Bahçıvan, Karadenizli varsa hallaç, Kayserili varsa pastırmacı paşazade yahut damat bey varsa Rakkakizâde'nin numaraları üstünkörü geçilir. Oyunu izlemeye gelenler arasında devletli bir kadın, faraza bir paşanın validesi yahut kayınvalidesi varsa, zennelerin anası Büyük Asım "zinhar fazla çaçaronluk” yapmaz, Kavuklu ile karşılaştığında kızlarının önüne düşüp "Kabaramazsın kel Fatma, annen güzel sen çirkin” şarkısını makamlı söylemez, hele aptal oğlanı kovalayıp dövmeye kalkışmaz.

Hamdi sahneye çıktığında kafasında beyaz tülbent sarılı dilimli kavuk, sırtında kırmızı cübbe, altında şalvar, ayaklarında çedik pabuç olur. Arkasında Kambur Mikail, Kambur Sadi ve Cüce Vasilaki yer alır. Pişekâr ile Kavuklu oyunun başında tanışıp ahbap çıkarlar, daha sonra Hamdi "Başıma gelenden haberin var mı cancağzım?" diyerek lafı açar. Kâğıthane’ye giderken kayığı alabora olmuş yahut Yakacık'ta bindiği at gemi azıya alıp kaçmıştır. Kavuklu, oyunun nihayetinde başına gelenlerin tümünün rüya olduğunu söyler. Hamdi’nin bu rüyaları elliyi aşkındır. (Alus 1948c: 2) 
O devirde Kavuklu dendiğinde onunla birlikte Küçük İsmail ve Kız Tevfik de hatırlanır. İsmail, tuluat üstatlarından kabul edilir. Abdürrezzak'ın “akıl hocal1ğından” gelmedir. Diğeri Kız Tevfik’tir. Sermet Muhtar, Kavuklu ortaoyunlarında zennelerden Kız Tevfik' in emsalsiz olduğunu, bir seferinde Fransa sefareti maiyetinde memur Pierre Loti'nin ortaoyununa götürüldüğünü, Kız Tevfik'in erkek olduğuna bir türlü inandırılmadığını söyler. ${ }^{7}$

Abdürrezzak Abdi: “Udhûke-perdaz-1 şehir” Abdürrezzak Abdi, Türk tiyatrosunda Dümbüllü İsmail'in geleneğini devam ettirenlerin ilki ve en meşhurudur. Sermet Muhtar, onu rahmetle anmamanın günah olacağını düşünenlerdendir. (Alus 1948ç: 2) Abdi, gençliğinde Şehzade Camii avlusundaki dükkânlardan birinde bıçak bileyiciliği yapmış, bedesten dellalı olmuş, zamanla oyunculuğa ilgi duyarak Şehremini'ndeki hastane çayırında, Topkapı dışındaki Kavas'ın bağında ortaoyunu zanaatına girmiştir. Alus, onun daha sonra Amerika tiyatrosuna "kapağı atıp", perdeli, kantolu komedyalarda oynadığını, Hanende-i Osmanî Kumpanyasını kurduğunu söyler. Yazları Bağlarbaşı'nın Beyleroğlu bahçesinde, ramazan aylarında Şehzadebaşı'nda tuluata başlamış, böylece meşhur olmuştur.

Tiyatrosunu hıncahınç dolduran Abdi’nin halkın muhabbetini, ekâbirin rağbetini kazanması II. Abdülhamid'i kuşkulandırmıştır. Sermet Muhtar Alus, padişahın Güllü Agop gibi, çanına ot tıkamak için Abdi'yi de Muzika-yı Hümayun kaydıyla saraya çektiğini ve biçarenin ocağına incir diktiğini söyler. Tarih “şehzadelerin sünnet düğününden birkaç ay önceye” rastlayan 1314'tür. (1898) Oysa Abdürrezzak Abdi, Abdülhamid sarayında Kavuklu Şükrü Efendi’nin ölümüyle boşta kalan kavuklu rolüne talip olduğunu Rıdvan Paşa’ya bildirerek saraya girmiştir.

İbiş'in yaratıcısı Abdürrezzak Abdi, Meşrutiyet'in ilanından sonra Vatan yahut Silistre piyesinde Abdullah Çavuş rolüne çıkmıştır. Seyirci önünde ilgi gördüğü son icrası bu olmuş, zamanla gözden düşmüştür.

Kel Hasan: Kafasının “dazlaklığından” dolayı bu lakapla anılır. Burnunun çöküklüğüyle ilgili ise birtakım rivayetler vardır. Salıncaktan düştüğü, Galatasaray’daki Avrupa tiyatrosunda Abdürrezzak’a yamaklık ederken, ustasının sinir-

7 Alus'un Kavuklu Hamdi hakkında bir başka yazısı: "Mama Mesiresinin Şaşaalı Zamanları, Hamdi Merhumun Orta Oyunları, Akşam, 16 Nisan 1931. 
lenmesiyle onu sahneden attığı ve burnunu yere çarptığı söylenir. Peruz'un belalılarından birinden aldığı darbeyle burunsuz kaldığı da konuşulur. (Alus 1934ç: 10) Kel Hasan, oyunculuğa 15-16 yaşlarında mesirelerde süt, yoğurt satarken başlamıştır. Kendisine ilgi gösterenlere komiklikler yapmıştır. (Alus 1950e: 186) O yıllarda Kuyubaşı'nda küçük bir evde, Hacı Fitil lakabıyla anılan, polislik de yapan abisinin yanında kalmaktadır.

Kel Hasan'ın Türk tiyatrosuna katkısı mesirelerde oynadığı salaş tiyatrolarla sınırlı değildir. O, Hayalhâne-i Osmanî adıyla bir kumpanya kurmuş, oyunlarını Direklerarası'nda, eski Hicaz valisi Saffet Paşazade hünkâr yaveri Miralay Esad Bey'in “akarlarından olan” önce Mehmed'in kıraathanesi iken sonraları tiyatroya çevrilmiş bir binada oynamıştır. Meşhur kantoculardan Peruz, Sahne-i Âlem adıyla kurduğu kumpanyası için bu binayı kiralayınca, Hasan, bir vakit Hilal sinemasının bulunduğu Şark tiyatrosuna geçmiş, 1908 Meşrutiyet'in ilanına kadar ramazanlarda ve kışları orada oynamıştır.

Hayalhâne-i Osmanî'nin gedikli aktörleri arasında kumpanyanın hem biletçisi, hem akıl hocas1, hem de "rejisörü” Kürklü Kâmil, Deveci Agâh, Küçük Asım, jönü Todori, kötü adamı Püzant, Külhanyan, Apik veya Garbis, mazlumu koruyan Rafail, başlangıçtaki bir perdelik komedyanın ibişi Kambur Mehmed, anne Alis, Küçük Virjini, hizmetçi kız Küçük Amelya vardır. Tiyatronun kantocuları ise Peruz, Peruz'un Şevki’ye "kapağı atmasından" sonra Küçük Virjini, Tereza, Büyük Amelya ve Küçük Amelya'dır. Tiyatronun müziklerini viyolonist Yorgi idare etmiştir. Perde aralarında kemanî Aşkî’nin altı kişilik incesaz takımı icrada bulunur.

Oyunlarının en meşhurları Rüyada Taaşşuk, Aş̧ılklar, Horozlu Düğün ve Gözlemeci'dir. Feerileri, Hindiana, Cahut, Seksen Günde Devr-i Âlem'dir. Komedi dramları, Kırmızı Kedi Meyhanesi, Gargeton Harabeleri, Serencaml Vasiyet, Meserretin Encamı, Bir Kadının Intikamı, Deniz Canavarları, Simon ve Mari yahud Perlaşez Kabristanı Cinayeti, Paris Paçavracısı'dır. Sermet Muhtar Alus'a göre Kel Hasan'ın tuluatta ustası Abdi'dir ancak o, emsalleri Arif, Atıf ve Şevki'den "kat kat" üstündür. Zeki, hazırcevap ve çâlâktır. Başta Abdi ve Küçük İsmail'in kumpanyasında külhanbeyi rollerine çıkan Kel Hasan, ustası Abdi'nin saraya alınmasının ardından Direklerarası'nın en meşhur ko- 
medyeni olmuştur. II. Abdülhamid saltanatının son yıllarına doğru epeyce para kazanmıştır. Cumhuriyet devrini de gören Hasan, 1929'da vefat etmiştir. ${ }^{8}$

Mesireler: Tanzimat sonrası İstanbul hayatında eğlence mesirelerle birlikte kamulaşmıştır. Önceleri kapalı ve daha özel mekânlarda icra edilen eğlenceler mesirelerin yaygınlık kazanmasıyla sokağa çıkmıştır. Lale devrinde henüz tam anlamıyla halkın kendisini ait hissetmediği, ancak Tanzimat'la birlikte her kesim ve yaştan insanın eğlenmek ve vakit geçirmek için tercih ettiği bu büyük sosyal mekânlara Alus, hemen her yazısında yer verir. Bu alanlara gidiş-dönüş hazırlıkları, oralarda yaşananlar, eğlenceler, mesire müdavimleri hakkında pek çok malumatı Alus'un yazılarında bulmak mümkündür. Mesireler ortaoyunu ve tuluatın yaygınlaşmasını sağlamıştır. Buralar, bahar ve yaz aylarında özellikle ikindiden sonra ve mehtaplı gecelerde kadınlı erkekli kabalıklarca tercih edilir. (Alus 1951: 592) Her akşam, Kadıköy civarında oturanlar maaile Kuşdili'ne gelir, Kel Hasan'ın oynattığı tuluatı izlerler. Meşrutiyetin ilanıyla birlikte Galatalı Hamdi Reis burada çalgılı bir tiyatro açmıştır. Hamdi, geçmişte Galata'da kumar kahvesi işletmiş, II. Abdülhamid'in yaveri Fehim Paşa'nın adamlarındandır. O devirde ramazan aylarının yaz mevsimine rastlaması dolayısıyla teravih namazlarının cemaatle çayırda kılındığını söyleyen Alus, namazdan sonra Kavuklu Hamdi'nin ortaoyunu oynadığını, küçücük sahnede kara kaşlı, kara gözlü Aranik' in "Muhaciriz, biçareyiz, ama ne bahtı kareyiz" diye kantolar söylediğini yazar. Kuşdili'ndeki tiyatro uzun yıllar Kel Hasan'ın oyunlarına da ev sahipliği yapmıştır.

Şaşkınbakkal'da, Çınardibi denilen muhitte Dümbüllü İsmail ve sair tuluatçıların sahne kurdukları bir başka mesire alanına Bolbedros denilir. (Alus 1948b: 2) Burası daha çok Kadıköy ve Üsküdar taraflarındaki Hıristiyanların müdavimi oldukları mesire alanıdır. 1900'lerin başında İstanbul'un en kibar mesiresi denilen Göksu'nun vazgeçilmez eğlencesi de salaş tiyatrolardır. Cuma ve Pazar günleri Komik Şevki'nin, Küçük İsmail'in, Şeyh Hakkı'nın tuluat kumpanyaları burada oynar, bazı zamanlarda da meydanda Kavuklu Hamdi'nin Zuhuri kolu temsiller verir.

8 Kel Hasan hakkında Alus'un kaleminden çıkmış diğer yazılar: "Komik-i Şehîr Hasan ve Kumpanyası”, Akşam, 19 Mart 1934; “Komik-i Şehir Hasan”, Aydede, 21 Ağustos 1948. 
Sermet Muhtar'ın en az söz konusu ettiği mesirelerden biri Mama'dır. Merdivenköyü civarında, Bektaşi tekkesi yakınlarında ağaçlar altında bir yerdir. (Alus 1931: 11) Mama, en şaşaalı devrini Hamdi’yle yaşamıştır. Kır kahvelerinde olduğu gibi çınar, sakız ağaçlarının altına konulmuş "mütevazı" tahta masalar, sandalyeler buranın havasına "samimiyet" katar. Kadınlar tarafi seyrek bir kafesle üstün körü ayrılmıştır. Kapı önünde Şişman Ahmed'in zurnası taksim icra eder. Hamdi'nin oğlu Enver Efendi de gişe önlerinde durur. Hamdi'nin ziyaretçileri arasında Keçecizade İzzet Fuad Paşa, Şehbender Kadri Bey, 31 Mart "şehitlerinden” Muzaffer Bey gibi pek çok meşhur sima bulunur.

Darülbedayinin kuruluşu sırasında, ortaoyunu ve tuluat toplumsal ve siyasal içeriğini kaybetmiş, sadece bir güldürü durumuna girmiştir. Özdemir Nutku, o devrin aydınlarının bu duruma eleştirel bir gözle bakmayı gerekli görmeden, geleneksel tiyatroyu aşağıladıklarını söyler. Ortaoyunu ve tuluatı ırkî bir hastalık ya da memleket sanatına ve tiyatrosuna zararlı görenlerin olduğunu iddia eder. (Nutku 2015: 5)

Karagöz: Edmondo de Amicis, "Karısının hâli hatırı sorulunca kulaklarına kadar kızaran aynı Türk, kız olsun, erkek olsun, çocuklarını, Karagöz’ün, duyguları uyanmadan evvel akıllarını karıştıran utanç verici edepsizliklerini dinlemeye gönderir." (Amicis: 1993: 138) demekten kendisini alamaz. Alus ise tam tersini yazar. Ona göre ramazan aylarında Karagöz ve meddah, çocukların hakkıdır. Bir tek kış ramazanlarındaki ayaz, çocukların tiyatroya, Karagöz'e götürülmelerine engel olabilir. Onlar, Kel Hasan'ın, Küçük İsmail'in, Şevki'nin hangi oyunu oynayacağını ilanlardan öğrenerek akşamı heyecanla beklerler.

Bu sanat Osmanlı toplumunda daha çok meddah kahvehanelerinde ve kıraathanelerde sahnelenmiştir. Devrin en meşhur meddah kahvehaneleri Beyoğlu'nda Kız Ahmed'in işlettiği mekân ile Divanyolu'ndaki Arif'in Kıraathanesi'dir. Divanyolu'ndan Sultanahmet parkına doğru sağ taraftan devam edildiğinde Firuzağa Camii'ne varmadan Doktor İzzet Kâmil'in ikametgâh olarak yaptırdı̆̆g, 1930’ların sonunda Esnaf Birliği Merkezi olarak kullanılan binanın iki kapı gerisinde, berberle ayakkabıcı dükkânının arasındaki çayevi, meşhur Arif'in kıraathanesidir.9 (Alus 1948a: 2) Alus, kıraathanede meddah olmadığ1 zamanlarda

9 Bu mekân hakkında bir başka yazı için: Sermet Muhtar Alus, “Arif’in Kahvesi”, İstanbul Ansiklopedisi, II. Cilt, s. 1007, 1959, İstanbul. 
Karagöz oynatıldığını ifade eder. Karagöz zamanlarında üzerinde sülüs, nesih, rik' a yazılarla "Hayali-i bînazir Kâtip Salih Efendi marifetiyle Alforvil Cinayeti yahut Denaetin Encamı komedi dram 9 perde, 4 tablo. Yeni kantolar, düettolar, ilh." yazan bir levha kapının dışına asılır. ${ }^{10}$ Kış günleri kıraathanenin camında kimlerin oyun sergileyeceği, hangi hikâyelerin anlatılacağı ilan edilir. Binbirdirek Batakhanesi, Şıngıllı Hanımla Mirasyedi Meftun Bey gibi hikâyeler bunlardan bazılarıdır. Salih, Hacivat oyunlarına modern sanatçılardan eklemeler yaptığından yaşlılar tarafından eleştirilir. Kâtip Salih için ramazan aylarında kış mevsiminde Cuma ve Pazar geceleri Direklerarası'ndaki Fevziye, Bayezid tramvay durağındaki Merkez kıraathanelerine de ilanlar asılır.

“Ortaoyununun ceddi” Karagöz, eski İstanbul'da sünnet düğünlerinde, ramazan gecelerinde bazı semtlerin büyük kahvelerinde oynatılan bir oyundur. Teravihlerden sonra camilerden çıkan efendibabalar, dedeler, çocuklarının ellerinden tutarak bu kahvelere giderler. (Alus 1950: 298) Sermet Muhtar, çocukluk yıllarında ve ilk gençliğinde Karagöz oynatanların çokluğundan bahseder. Aşağı tabadakiler Ayvansaraylı, Eğrikapılı, Tophaneli ve Üsküdarlı'dır. Kalburun ardından gelen hayaliler ise Kâtip Salih, Şair Ömer, Koskalı Mehmed, Tatar Raşid, Arap Cemal ve Dönme Hususi' dir. Kâtip Salih, ramazan ayı boyunca kış mevsiminin Cuma ve Pazar geceleri Şehzadebaşı'nda Fevziye, Vezneciler'de Şems, Bayezid tramvay durağında Merkez, Divanyolu'nda Arif'in kıraathanelerinde Karagöz oynatmıştır. Eski İstanbul'da Karagöz oynatanların en meşhurlarındandır. (Alus 1942b: 1) Düğünlerde özenerek bir cemiyet tertip etmek isteyenlerin Kâtip Salih'i davet ettiği, rakı tepsisini henüz o gelmeden hazırladığı, aksi takdirde hayalinin neşesini bulmasının zor olacağı söylenir. (Alus 2005: 105) Hayalî Salih Umumi Harp yıllarında perişan bir hâldedir. Askerî Müze'de mehterhâne bandosunda çalmış, üç beş defa da müze sinemasında Karagöz oynatmıştır.

Kâtip Salih'in yaşlanıp gözden düşmesiyle Şair Ömer, “yepyeni bir hayalı̂”, olarak ortaya çıkmıştır. Asıl adı Fahri'dir. Kalem kâtipliğinden yetişmiş, edep erkân bilir, otuz beşlik bir zâttır. Okuryazarlığı, dilinin düzgünlüğü, hazırlanmadan secili cümleler kurabilmesi dolayısıyla şair lakabıyla anılır. İlk çıkışında Vezneciler'deki Şems kıraathanesine perdesini kurmuş, camlara cafcaflı ilanlar asmıştır. 
Oyunlarının arasına zamana uygunluk katmayı bilmiştir. Karagöz'ün “ölü mevsimi olan yazları" kazancını Kavuklu Hamdi'nin Mama, Libade, Hünkârsuyu'ndaki ortaoyunlarına Hanımnine, Büyük Asım'ın arkasında baş zenneliğe çıkarak kazanmıştır. Zennelikte Kız Tevfik’ten de üstün bir maharete sahiptir.

Arap Cemal, musiki üstadı meşhur Hacı Kirami'nin oğludur. Hacı Kiramî, veliahd Reşad Efendi’ye birkaç akşam iftara gittiği, teravihte müezzinlik yaptığ için mimlenmiştir. Arap Cemal, devrin siyasi karmaşasında babası takibe uğramadan önce Ereğli mahallesindeki evinden boyuna çağırtılır, büyük konaklarda Karagöz oynatır, meddahlık yapar, harikulâde muvaffak olduğu Kayserili pastırmacının, Rumelili Arabacı'nın taklitleriyle adından söz ettirir bir Karagözcüdür. Cemal, Taşkasap'taki Fındıkzade, Haseki'deki Paşmak Şerif, Etyemez'deki Kadem, Nuruosmaniye'deki Özbek tekkelerinde, Topkapı, Kasımpaşa, Beyoğlu Mevlevihanelerinde zâkirlik, muharremlerde mersiye okuyuculuğu yapmıştır. Çanakkale'de Arıburnu'nda şehit düşmüştür.

Beşiktaşlı Ahmed Hususi, Anadolu Ermenilerinden bir mühtedidir. Önceler Karagöz oynatmış, İkinci Abdülhamid devri sonlarında kuklacıllğa başlamıştır. (Alus 1958b: 373) Önünde zilli laterna, yardağının sırtında kukla sand1ğ1 ve perdesi, Kadıköy'de, Çamlıca'da, Boğaziçi’nde köşk köşk, yalı yalı gezer, kukla oynatır bir sanatçıdır. Yanında gezdirdiği Habeş bir çocuktan bahsedilir. Abdülaziz devrinde Güllü Agop'un Gedikpaşa'daki tiyatrosundan yetişmiş, Tospatyanla, Baltazarla beraber komiklikler yapmıştır. Beşiktaş’ta oturmuş, sefalet içerisinde vefat etmiştir.

Karagöz kamuya açık mekânlarda oynanmanın yanında kimi zaman aile meclislerinde de kendisine yer bulmuştur. Alus, Karagöz meraklılarının başında eski dava vekillerinden Kabakulak namıyla maruf Sami Efendi'nin geldiğini söyler. Sami Bey, Kâtip Salih’ten daha "mütekâmil” ve nükteli Karagöz oynatan bir zât olarak anılır. ${ }^{11}$ Eski İstanbul'da eş-dost arasında oynanan ortaoyunları da olmuştur. Manyasizade Refik Bey'in Kavuklu rolünü, Hamdi'den daha mükemmel bir biçimde taklit ettiğinin söylenmesi bu oyunları eş dost meclislerinin d1şına taşımış olmalıdır. Kurban Oseb, Paskal Sami, Borazan Tevfik, Kadıköylü Refik, Paskal Salih, ressam Muazzez, Üsküdarlı Etem gibi hem taklitte hem de 
zarafet ve nüktede eşi bulunmayanlar çıkmıştır. Paskal Sami, Mınakyan'ın bütün oyunlarını, bilhassa La Dame aux camélias, Balmumcu, Ekmekçi Kadın'1 tek başına oynayacak kabiliyettedir. Sermet Muhtar burada, bir zamanlar Hayal, Geveze gibi mizah gazetelerine karikatürler çizen Ahmet Münir'i de unutmamak gerektiğini söyler. $^{12}$

Direklerarası: Bugün Vezneciler'den Şehzadebaşı camiine kadar olan cadde, eski İstanbul hayatının vazgeçilmez eğlence mekânlarından Direklerarası adıyla bilinirdi. Lale devri sadrazamı Damat İbrahim Paşa'nın sebil ve külliyesine gelir sağlamak amacıyla yaptırdığı revaklı çarşının sütunlarından dolayı bu adı almıştır. 1880'de Güllü Agop'un tekeli sona erince burada birçok topluluk ortaoyunu ve tiyatro gösterileri yapmıştır.

Direklerarası, piyasa tabiri ile birlikte kullanılır. Modernleşen Osmanlı toplumu kadın erkek münasebetlerinin başladığı mesire alanlarını Direklerarası'na taşımıştır. Tanzimat'tan Meşrutiyet'e Türk romanında onlarca hikâyesini okuyabileceğimiz bu muhit, ramazan aylarında tiyatrolarla hareketlenir. İkindiden iftara, iftardan sahura tercih edilen Direklerarası'nda asıl eğlence iftardan sonradır.

Abdürrezzak'ın Handehâne-i Osmanî Kumpanyası, Kel Hasan'ın Hayalhâne-i Osmanî Kumpanyası, Mınakyan'ın Osmanlı Dram Kumpanyası ramazan aylarında Şehzadebaşı'nda toplanmışlardır. (Alus 1947c: 4) Abdi'nin saraya alınmasıyla onun üslubunu Kel Hasan ve Şevki devam ettirmiştir. (Alus 2005: 56) Telgrafhanede kâtip olan Şevki, kantocu Peruz ve Şamram'la Eğlencehâne-i Osmanî adında bir kumpanya tesis etmiştir. Bu ekiplerin hepsi ramazanın otuz günü ve üç bayram günü Direklerarası'ndadır. Sahur davulları vuruluncaya kadar kıraathaneler ve cadde insanla doludur. Bu kalabalık ramazandan sonra yerini sessizliğe bırakır.

Kel Hasan önceleri Mehmed'in gazinosunda, sonraları Hilal Sinemas1 olan Şark Tiyatrosu'nda; Şevki, Letafet Apartmanı'nın karşısındaki binada, Abdi'nin "bakayası" da bazen Ferah'ın olduğu yerdeki tiyatroda, bazen de yakınlarındaki ahşap bir tiyatroda oyunlarını oynamışlardır. Yaz aylarında bu tiyatrolar, Cuma ve Pazar günleri Kuşdili çayırı civarındaki salaş mekânlarda, 
hafta arasındaki bazı günlerde de Bağlarbaşı, Mama ve Libade'de sahnelerini kurmuşlardır.

Önceleri Mehmed'in kahvesi adıyla bilinen, sonra Millî Sinemaya dönüşen tiyatro dışarıda tutulursa, Direklerarası'nın tiyatroları salaş, ahşap, üstelik bakımsız yapılardır. Devrin İstanbul'unda daimi, kârgir bir tiyatro binası bulunmadığından topluluklar yaz mevsiminde mesire alanlarına, ramazan günlerinde Şehzadebaşı'na kolaylıkla taşınabilirler. Locaların önü kırmızı astarlarla süslenir. Bu sebepten omuz omuza olunduğu hâlde 1sınmaz, izleyiciler soğuktan çivi keserler. Tiyatrolar kalabalık, gürültülü, sigara dumanı altında bin bir satıcıyla hareketlenen yerlerdir. Bundan olsa gerek saz faslı kısa sürer hatta Alus'un deyimiyle gümbürtüye gider. Baştaki tek perdelik komedyayı da ayaktakımından başka izleyen olmaz. Kantolara sıra geldiğinde temaşa kıvam tutmaya başlar. Kantonun ardından asıl tuluat, şarkılı oyun, feeri ya da komedi dram gelir.

\section{İstanbul'un Gönlünü Hoş Edenler}

Kambur Sadi: 14-15 yaşlarında hem öksüz hem yetim kalmış, hovardalığa kendisini bırakmış, mektepten kurtulmanın yollarını aramış en nihayetinde Hamdi'nin Mama'daki ortaoyununda, Kavuklu'nun ve Göztepeli Refet'in ardında meydana çıkmıştır. Kel Hasan, Şevki ve seyyar tuluat kumpanyaları ile Anadolu'da, Rumeli'de, Suriye'de oynamış, dolaşmadık yer bırakmamıştır. Amerika ve Avrupa'yı görme hevesini bir gün Mısır hıdivinin bandosunda çalan Kamil ile haberleşerek gizlice Hıdıviye vapuruna binerek sağlamıştır. Önce İskenderiye'ye gitmiş, bir yolunu bularak Bulgaristan'daki Benliyan kumpanyasına katılmıştır. Trieste'den İtalya'ya geçmiştir. Sadi, musikiye ve lisana karşı kabiliyetli, ustasız, meşksiz âlâ flüt çalabilen, Fransızca, Arapça, Rumca ve Ermenice anlayan bir oyuncudur. Alus, Kambur Sadi'yi ilk defa bir akraba düğününde gördüğünü, Sadi’nin başına havuza düşmek gibi talihsiz bir olay geldiğini yazar. ${ }^{13}$ (Alus 1934: 11) Kambur Sadi, Alus'un sütkardeşi Ali ile aynı mektepte okumuştur.

Sahneye Çıkan İlk Türk Kızı Afife: Bedia Muvahhit'in sahneye çıkışının 25. yıldönümünde gazetelerde haberler, radyolarda konuşmalar yapılmış, 
Açıkhava Tiyatrosu'nda kutlamalar düzenlenmiştir. Sermet Muhtar Alus'a, Bedia Muvahhit etrafında cereyan eden bu haberler sahneye çıkan ilk Türk kızı Afife Jale'yi hatırlatmıştır. Kaleme aldığı bir yazıda Afife'yi bir dost meclisinde nası1 tanıdığını anlatır. (Alus 1950d: 5) 1917 yılı kışında bir ahbabının evine gidip geldiğini, ${ }^{14}$ evin hanımının, o y1llarda İstanbul'da Viyana Opereti'nin primadonnası Miloviç'in Halep Çarşısı'ndaki tiyatroda verdiği Çardaş, İstanbul Gülü, Şen Dul gibi temsillerinden esinlenerek piyanoda mersolar, udla şarkılar çaldığını ifade eder. Bu davetlerin birinde Afife Jale de bulunmuştur. Alus, söz konusu yazida bu hususi tanışıklı̆ğın intibalarından bahsetmeyi tercih etmemiştir. Afife'nin 1923 'te Kadıköy'deki Hale Tiyatrosu'nda Darülbedayi sanatçıları arasında bir Türk kızı olarak nasıl sahneye çıktığını, zabıtanın oyuna müdahalesini ve "zavallı” Afife'nin karakola götürülmesini anlatmıştır.

Cerrahpaşalı Küçük Ali: Bir devrin meşhur simaları arasında Langalı Şemsi, Cerrahpaşalı Küçük Ali, Nabi İsmet, Aşkî, Süruri gibi meddahlar da bulunur. (Alus 1942: 3) Cerrahpaşalı'nın Rum, Ermeni, Frenk taklitleri eşsiz kabul edilir. Saraçhanebaşı'nda, mayiat deposu olan bir dükkânda, hekimlik yapan, hastalarına atla gittiği için Atlı Doktor denilen İstrati’ye çok benzeyen Ali, ramazanlarda zaptiyelerden yakasını bu meziyetiyle kurtarır. Kahvede, çaycıda ramazan günü oruç tutmadığ1 görüldüğünde karakola haber verecek birini fark ederse İstrati gibi Rum ağzıyla konuşmaya başlar, jurnallenmekten kendisini kurtarırmış.

\section{Sahne Sanatçıları}

Sermet Muhtar Alus'un yazılarında, özellikle ansiklopedi maddelerinde sözünü ettiği pek çok sahne sanatçısı olmuştur. Sözgelimi Arap Ahmed, ortaoyununda Şetaret Kalfa'ya çıkan son orta oyuncularındandır. (Alus 1958: 229) Halk ağzında Tekkekapısı denilen Üsküdar'daki Selami Ali Efendi Mahallesi bekçilerindendir. Ahmed Necib Efendi, ilk Türk aktörlerindendir. (Alus 1958c: 401) Güllü Agob'un Gedikpaşa'daki Osmanlı Tiyatrosu'nda şöhretinin en parlak yıllarını yaşamıştır. 1896-1897'ye kadar Mınakyan'ın kumpanyasında bulunmuştur. İdbar ve İkbal adında bir piyes de kaleme almıştır. 1898'de vefat etmiştir. Sepetçi Ali Rıza, son ortaoyuncularından ve tuluat komiklerindendir. 
(Alus 1959a: 701) Abdürrezzak Kumpanyası'nın başlıca simalarından olduğu söylenir. Sermet Muhtar, Abdürrezzak'ın 1880-1882 yılları arasında oynadığ Bursalı Leylâ adlı komedisinin on artistinden altısının Türk olduğunu, o zamandan kalma bir el ilanında gördüğünü ifade eder. Bu altı Türk, Abdürrezzak, Hamdi, Mukbil, Salih, Mehmed ve Ali Rıza'dır. Ali Rıza, Meşrutiyet'in ilanına kadar Abdi, Kel Hasan, Şevki'nin kumpanyalarında komiklik yapmıştır. Kavuklu Hamdi'nin, Kel Hasan'ın, Mama ve Libade'deki ortaoyunlarında “Aptal Adam” taklidine çıktığı bilinir. 1930-1935 yılları arasında İstanbul'da çekilmiş bir iki yerli filmde de rol almış, II. Dünya Savaşı'nın başlarında vefat etmiştir. Kız Anastas, tuluatın son devrinde sahneye çıkmış oyuncu komiklerdendir. Mütareke senelerinde ve Cumhuriyet'in ilk y1llarında tuluat tiyatrolarında oynamıştır. Gözleri şaşı bir Rum gencidir. Alus, "ahlaksızlık ve küstahlığının neticesi olarak” sınır dışına çıkarıldığını ve dönmesinin yasaklandığını söyler. (Alus 1959b: 838) André Antoine, Fransız aktör ve tiyatro adamıdır. Darülbedayi'nin ilk teşkilatını kuran ve İstanbul'da "maalesef" faaliyetine devam edememiş Tiyatro Mektep Akademisi'ni açan sanatkârdır. 1913’ü takip eden aylarda İstanbul Şehremini Cemil Topuzlu (Cemil Paşa) İstanbul'da kurmak istediği Konservatuvar için André Antoine’a bir teklif mektubu göndermiştir. Bu davet üzerine İstanbul'a gelen Antoine, bir rapor hazırlamıştır. Raporun kabul edilmesiyle birlikte 1914'te Darülbedayi-i Osmanî adı ile ilk Türk tiyatro teşkilatı tesis edilmiş, müdürlüğüne de Antoine getirilmiştir. Mektep binası için Şehzadebaşı'ndaki Letafet Apartmanı uygun görülmüş, gazete ilanlarıyla da talebe alımına başlanmıştır. Kadın ve erkek 197 kişi müracaat etmiş, yapılan imtihan neticesinde 63 kişinin kaydına onay verilmiştir. Dersler ve dersleri okutacak hocaların belirlenmesinden kısa bir süre sonra savaşın getirdiği siyasî sonuçlar Antoine'1 ülkesine dönmek zorunda bırakmıştır. (Alus: 1959c: 882) İngiliz işgal askerlerinin 1918 Kasım'ında Tünel'den Taksim'e gövde gösterisi yaparak yürümeleri sırasında Pera halkının Rumca tezahürat yapmaları, bayrak sallamaları Antoine'dan sonra azınlık tiyatrosunun sonunu getirmiştir. Araksi Hanım, Benliyan Kumpanyasının ve daha sonraki bazı kumpanyaların aktrisidir. (Alus 1959ç: 964) Cemal Sâhir Kumpanyası'nın başkadın rollerini oynamış, "primadonnalık” yapmıştır. Ses ve vücut güzelliği ile Ermeni 
sanatkârlar içinde devrinin en meşhurlarındandır. Bayzar Hanım, tuluat sanatçıs1, Ermeni bir aktristir. (Alus 1961a: 2324) Abdürrezzak'ın, Kel Hasan'ın, Küçük İsmail'in, Şevki'nin kumpanyalarında oynamış, Alus'a göre tuluatta eşi bulunmayanlardandır. Samatya ağzı ile konuştuğu ifade edilir.

Binemeciyan (Agavni-zebed), Rupen Binemeciyan'ın karıs1, Eliza Binemeciyan ile Onnik Binemeciyan'ın anneleridir. (Alus 1961b: 2794) Minakyan Tiyatrosu'nun aktrislerindendir. 1922'de ölmüştür. Eliza Binemeciyan, 1890'da İstanbul'da doğmuştur. Babası Rupen Binemeciyan annesi Agavni Binemeciyan'dır. Sermet Muhtar, A. Madat'ın Sahnemizin Değerleri adlı kitabına dayanarak Eliza'nın, Kadıköy'deki Notredame de Sion Fransız Kız Mektebi'nde okuduğunu söyler. 1900'de henüz on yaşında iken Mınakyan Kumpanyası'nda sahneye çıkmıştır. Profesyonel sahne hayatı ise 1908'de Meşrutiyet'in ilanından sonra, birkaç gencin kurduğu Serbest Sahne'de Ermenice oynanan Victor Hugo'nun Kral Eğleniyor dramında Blanche rolüne çıkarak başlamıştır. Serbest Sahne'de iki ay kaldıktan sonra Mınakyan Kumpanyası'na geçmiştir. Zaman zaman Donanma Cemiyeti Heyet-i Temsiliyesi'nde, Yeni Sahne'de ve Darülbedayi'de “mümtaz mevkii olan sanatkâr" unvanıyla sahneye çıkmıştır. Darülbedayi'de bulunduğu yıllar sanatının en parlak yıllarıdır. Evlendikten sonra 1924'te Fransa'ya gitmiş, Raşid Rıza'nın daveti üzerine o yılın ramazan ayında İstanbul'a gelmiş, Rıza'yla birlikte Fransız Tiyatrosu'ndaki temsillere katılmıştır. Sonra temelli Fransa'ya dönmüştür. (Alus 1961c: 2795) Onnik Binemeciyan, Rupen ve Agavni Binemeciyan'ın oğludur. Eliza Binemeciyan'ın büyük kardeşidir. Darülbedayi’ye katılmış, I. Cihan Harbi mütarekesinde Amerika'ya gitmiştir. (Alus 1961ç: 2795) Rupen Binemeciyan, 1885'ten 1908'e kadar İstanbul'da Osmanlı Dram Kumpanyası'nı yöneten Mınakyan’ın “jönprömiyerliğini” yapmış Ermeni aktördür. (Alus 1961d: 2796) Eliza ve Onnik Binemeciyan'ın babasıdır. 1910'da ölmüştür. Gedikpaşa'daki Güllü Agop'un tiyatrosunda rejisörlük yapan, sonra bir trup kuran Fasulyacıyan'ın yetiştirmelerindendir. Binemeciyan ise Mınakyan Kumpanyası'nın âşıklığa çıkan aktörüdür. (Alus 1941b: 4) Karısı da genç kız rollerini alır. Eliza ve Onnik Binemeciyan çocuklarıdır. Binemeciyan'la Hekimyan, Mınakyan'ın tiyatrosunda mütemadiyen karşılıklı oynamışlardır. (Alus 1934b: 12) Binemeciyan mostra âşık, Hekimyan da mostra maşuka rollerindedir. Binemeciyan, kaşları, gözleri, bıyıkları, rastığı bulan- 
mış gibi zifiri siyah, sinekkaydı tıraş üzerinde kat kat pudralar sürünür. Gözleri sürmeli, yanakları pembe pembedir. Alnının bir tarafında bombe biçiminde kabartılmış kâkül bulunur. Elinde ayna gibi parlayan silindir bir şapkası vardır. Bacaklarında mayoya benzer, yapışık kısa beyaz bir pantolon, altında siyah çoraplar, rugan iskarpinler. Şivesi, İstanbul şivesine yakındır. Konuşması hanımların hoşuna gider. Yürüyüşü vakur ve olgundur.

Şişko Ahmed, Lonca Çingenelerinden meşhur bir zurnacıdır. Loncanın üstündeki Hançerlibostan'da zurna çaldığında Haliç'in karşısında, Tepebaş1 Bahçesi'nden dinlendiği rivayet edilir. Bir zaman, Kavuklu Hamdi’nin ortaoyunu takımında zurnacılık yapmış, ömrünün son yıllarında köy dügüunlerinde ve pehlivan güreşlerinde zurna çalmıştır. (Alus 1958d: 316) Kemanî Aşkî, İkinci Abdülhamid devrinde Ayvansaray'da Lonca'da yetişmiş sazendelerdendir. Alus, Aşkî’nin ikinci derece kemancılardan olduğunu söyler. "Üstadkâri eski besteleri, kârları, peşrevleri pek beceremez fakat kiriz havaları denilen oyun havalarında, köçeklerde, kabadan çiftetelli çalışta yayı çok curcunalı ve şakraktı.” denilen Aşkî, Kel Hasan'ın tuluat tiyatrosunda oyun başlamadan önce ve perde aralarında beş kişilik ekibiyle fasıllar icra etmiştir. (Alus 1960: 1170) Apukurya zamanlarında Odeon ve Konkordiya Tiyatrolarında, maskeli balolarda ekibiyle ahenk tutturduğu bilinir. Şişman Ağavni, Abdülhamid devrinde Galata’nın "batakhane” tiyatrolarındaki meşhur kantocu kızlardandır. (Alus 1958e: 252)

\section{Sonuç}

Sermet Muhtar Alus, son dönem Osmanlı devlet adamlarından Muhtar Paşa'nın oğludur. Çocukluğu ve ilk gençliği devlet erkânı içerisinde geçmiş, varlıklı bir hayat sürmüş, hayat gailesi çekmemiştir. Bu refah onda İstanbul'un eğlence cemiyetlerini daha yakından tanıma imkânına dönüşmüş, Alus, özellikle tiyatro ve müzik mirasımızı görerek, dinleyerek, tanışarak tecrübe etmiştir. Çocukluk yıllarından itibaren çevresindeki bu kültürü kayıt altına almış, irili ufaklı mizah dergilerinde çizimler yapmış, tuttuğu kayıtları Cumhuriyet devrinde yazıya geçirmiştir. 1930'ların başından 1952'deki vefatına kadar, hatta vefatından sonra da yayımlanacak İstanbul yazıları kaleme almıştır. Bazı günler birden fazla gazetede Alus imzasına rastlamak mümkündür. Bu yazılarda, 1850’lerden Meşrutiyet yıllarına 
kadar İstanbul folkloru yer alır. Ancak bu makalede Alus'un söz konusu yazılarına yansıyan eğlence kültürü ve özellikle Türk tiyatrosu ele alınmıştır.

Güllü Agop'a, Sultan Abdülaziz'in iradesi ile verilen on yıllık oyun oynama tekeli batılı anlamda Türk tiyatrosunun başlangıcı kabul edilir. Agop, daha çok adapte ve çevirilerle yaşatmaya çalıştığı tiyatrosunda ramazan aylarını Türkçe oyunlara ayırmak ve İstanbul'un farklı muhitlerinde sahneler kurmak mecburiyetinde olduğu için modern Türk tiyatrosunun kurucularından kabul edilir. Ancak birtakım politik gerekçelerle, Gedikpaşa'da kurduğu Osmanlı Tiyatrosu'nun ortadan kaldırılması ve Güllü Agop'un saraya alınmasıyla uzun yıllar Türk tiyatrosundan bahsetmek mümkün olmayacaktır. Güllü Agop'a verilen imtiyazdan kendilerini kurtararak tiyatro çalışmalarını sürdürmek isteyen sanatçıların arayışları tuluatı ortaya çıkarmıştır. Modern bir tiyatro var etmek için çıkılan yolculuk sansürle sonuçlanmış yerine ikame edilen tür geleneksel Türk tiyatrosuna yeni bir şube kazandırmıştır. Ortaoyunundan küçük farklılıklarla ayrılan tuluat Türk sanatçılar elinde özellikle Direklerarası'nda kurulan tiyatrolarda ihtişamlı günlerini yaşamıştır. $\mathrm{Bu}$ süreç 1910'da Direklerarası'nın yol genişletmek bahanesiyle ortadan kaldırılmasına kadar devam etmiş, 1914'te Darülbedayi ile tamamen son bulmuştur.

Tuluatın öncesinde Türk tiyatrosu kahve ve kıraathanelerde gösterilen Karagöz ve mesire alanlarına kurulan salaş tiyatrolarda icra edilen ortaoyunu ile genişlemiştir. Alus, bu türlerin tamamını ilkgençliğinde izlemiş ya da daha yaşlılardan bu sanatlara dair malumat toplamıştır. Süreli yayınlarda çıkan yazılarının dışında Alus'un romanlarında da Türk tiyatro tarihine dair zengin bir malzeme bulunur. Özellikle Nanemolla, vakanın tamamı Gedikpaşa tiyatrosunda geçiyor olmasından dolayı bir belge niteliği taşır. Kitapta yer alan Osmanlı Tiyatrosu çizimi de mekânın zihinlerde biçimlenmesini sağlamıştır.

Sermet Muhtar Alus'un yazılarında tiyatro faaliyetlerinin yürütüldüğü mekânların çeşitliliği göze çarpar. Semai kahvelerinden mesire alanlarına, gazino ve meyhanelerden sinema salonlarına kadar oldukça geniş bir alanda modern ve geleneksel tiyatro oyunları ile batıdan gelen kumpanyaların ${ }^{15}$ gösterileri bu yazıların içeriğini oluşturur. Burada, Galata meyhanelerinde oynanan tiyatrolar, kantoya çıkan kadınlar da vardır, teravih namazlarından sonra sırtlarında cübbeleriyle sahneye koşan tuluatçılar da.

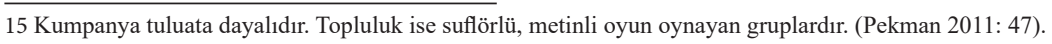


Sermet Muhtar Alus, devrin gazetelerine de yansıdığı üzere paşazâde bir muharrirdir. Osmanlı'nın son devrini devlet katına mensup bir aile içerisinde geçirmiş, II. Abdülhamid'e "istibdat" ve hafiyecilikten sebep muhalif olsa da bu kültürün bütün kurum, hadise ve kişilerini kayıt altına almıştır. Ancak düzenli bir biçimde yazması Cumhuriyet yıllarında olmuştur. Bu durum, maişetini temin etmek maksadıyla ortaya çıkmış olmalı yönündeki iddia, Alus'un yazdıkları dikkatle okunduğunda mesnetsiz kalmıştır. $\mathrm{O}$, çocuk denecek yaşlarda etrafinda olup bitenlere tepki veren, bunları bir gün yazacağı umuduyla kayıt eden bir isimdir. Elbette 1930'larda birden yoğun bir biçimde yazması tesadüfe bırakılamaz. Öncelikle, bütün yazı mesaisini İstanbul'a harcaması, bu şehrin o yıllarda gözden düşürülmüş, reddedilmiş, bakımsızlığa muhtaç bırakılmış olmasına bir tepkidir. Cumhuriyet, mamur edilecek şehir tercihini Ankara'dan yana kullanmış, Osmanlı Devletine yüz yıllarca payitaht olmuş bir şehir, eskinin toptan reddi politikaları içerisinde kasten ihmal edilmiştir. $\mathrm{Bu}$ ihmal, fizikî yapının bozulmasından öte asırlarca örülen kültürün yok olmasını getirmiştir. Sermet Muhtar Alus, devletçi ve milliyetçi politikalarla içe kapalı idari sistemin çok kültürlü, çok sesli İstanbul hayatını tüketmeye başladığının farkındadır. Bu çalışmada odak, Türk tiyatrosu olduğu için bu çerçevede kalarak söylemek mümkündür ki, bir dönemin büyük sanatçıları Meşrutiyet'ten sonra unutulmuş, kimileri yokluk içerisinde hayatını kaybetmiş, kimileri de Avrupa ülkelerine göç ederek bir hafızayı beraberlerinde götürmüşlerdir. Alus, bu hafizanın ebediyen yok olmaması için her gün ısrarla İstanbul'un folklorunu yazmıştır.

Bu makalede görülmüştür ki o, İstanbul'u medeniyet, din, tarih bilinciyle değerlendiren bir isim değildir. Onda, Süleymaniye Camii'nin, çeşmelerin, hatların, mezar taşlarının, türbelerin bahsi yoktur. Alus, arka sokakların hikâyecisidir. Bu hususiyetiyle Ahmed Rasim'in çizgisini sürdürür. Bugünden bakıldığında son dönem Osmanlı toplumunun sokak seslerini duymak onun yazdıkları sayesinde olur. $\mathrm{Bu}$ güç, Türk tiyatrosu mevzubahis olduğunda daha da değerlenir ve Alus'un yazdıkları göz ardı edilerek ne azınlıkların sanat mirası ne de Türk oyuncuların çalışmaları hakkıyla yorumlanabilir. Burada, bir sanat icra etmek üzere kalabalıklar önüne çıkan kim varsa söz konusu edilmiştir. 


\section{Kaynakça}

Ahmed Cevdet Paşa (1980), Ma rrûzât, hzl. Yusuf Halaçoğlu, İstanbul: Çağrı Yayınları.

Aksel, Malik (2011), İstanbul'un Ortası, hzl. Beşir Ayvazoğlu, İstanbul: Kapı Yayınları.

Alus, Sermet Muhtar (2005), 30 Sene Evvel İstanbul, hzl. Faruk Ilıkan, İstanbul: İletişim Yayınları.

Alus, Sermet Muhtar (1938.12.28), "Eski Kıraathaneler”, Akşam, s. 11.

Alus, Sermet Muhtar (1947.11.5), "Eski Beyoğlu Barları”, Akşam, s. 4.

Alus, Sermet Muhtar (1931.4.16), "Mama Mesiresinin Şaşaalı Zamanları, Hamdi Merhumun Orta Oyunları”, Akşam, s. 11.

Alus, Sermet Muhtar (1941.8.31), "Manakyanın Meşhur Aktörü Binemeciyan”, Akşam, s. 4.

Alus, Sermet Muhtar (1939.3.14), “Kavuklu Hamdi, Peşekârları, Zenneleri, Taklidleri”, Akşam, s. 10.

Alus, Sermet Muhtar (1947.7.9), “Demirhane Müdür”, Akşam, s. 4.

Alus, Sermet Muhtar (1950.7.5), “Leonidas'ın Varyete Kumpanyası”, Akşam, s. 5.

Alus, Sermet Muhtar (1947c.11.19), "Eski Tiyatrolardan Hâtıralar”, Akşam, s. 4.

Alus, Sermet Muhtar (1950d.9.6), "Sahneye Çıkan İlk Türk Kızı: Afiff”, Akşam, s. 5.

Alus, Sermet Muhtar (1942.10.4), "Eski Meddahlar”, Yeni Sabah, s. 3.

Alus, Sermet Muhtar (1942.9.27), "Hayalî Kâtip Salih”, Yeni Sabah, s. 1.

Alus, Sermet Muhtar (1947ç.7.11), "70 Y1l Evvelin Hanendesi Beşiktaşlı Sofi”, Akşam, s. 4.

Alus, Sermet Muhtar (1948a), “Arif'in Kiraathanesi”, Aydede, 3 Kasım, s. 2.

Alus, Sermet Muhtar (1948b), "Bolbedros”, Aydede, 18 Ağustos, s. 2.

Alus, Sermet Muhtar (1948c), "Kavuklu Hamdi ve Ortaoyunu”, Aydede, 4 Eylül, s. 2.

Alus, Sermet Muhtar (1948ç), "Udhuke Perdaz-1 Şehir Abdürrezzak”, Aydede, 2 Ekim, s. 2.

Alus, Sermet Muhtar (1948d), "Eski Kantolar ve Kantocular”, Aydede, 6 Ekim, s. 2.

Alus, Sermet Muhtar (1948e), "Eski Kantolar ve Kantocular II”, Aydede, 9 Ekim, s. 2.

Alus, Sermet Muhtar (1951), "Eski Kuşdili, Yoğurtçu, Kurbağalıdere”, Resimli Tarih Mecmuası, Şubat, S. 14, s. 592-594.

Alus, Sermet Muhtar (1950), "Eski Milli Tiyatromuz: Orta Oyunu”, Resimli Tarih Mecmuası, Temmuz, S. 7, s. 266-268.

Alus, Sermet Muhtar (1950), “Karagöz”, Resimli Tarih Mecmuası, Ağustos, S. 8, s. 298-300.

Alus, Sermet Muhtar (1950c), "Mınakyanın Osmanlı Tiyatrosu", Resimli Tarih Mecmuası, Mart, S. 3, s. 104-110.

Alus, Sermet Muhtar (1951), “Eski Galata'nın Eğlence Yerleri”, Resimli Tarih Mecmuası, Mart, S. 15 , s. $640-642$. 
Alus, Sermet Muhtar (1950), “Kel Hasan'ın Hayalhane-i Osmani Kumpanyası”, Resimli Tarih Mecmuası, May1s, S. 5, s. 186-189.

Alus, Sermet Muhtar (1934), "Kambur Sadi”, Yedigün, 20 Haziran, S. 67, s. 11-13.

Alus, Sermet Muhtar (1934b), “İstanbulun Eski Greta Garbo'su ve Ramon Novaro'su Kimlerdi?”, Yedigün, 5 Eylül, S. 78, s. 12-13.

Alus, Sermet Muhtar (1934c), “Kantocuların Kadınnesi Peruz”, Yedigün, 11 Temmuz, S. 70, s. 10-11.

Alus, Sermet Muhtar (1934), “Kel Hasan”, Yedigün, 18 Temmuz, S. 71, s. 10-11.

Alus, Sermet Muhtar (1958), “Ahmed (Arap)”, İstanbul Ansiklopedisi, C. I, s. 229.

Alus, Sermet Muhtar (1958), “Ahmed Hususi”, İstanbul Ansiklopedisi, C. I, s. 373.

Alus, Sermet Muhtar (1958), “Ahmed Necip Efendi”, İstanbul Ansiklopedisi, C. I, s. 401.

Alus, Sermet Muhtar (1959), “Ali Rıza (Sepetçi)”, İstanbul Ansiklopedisi, C. II, s. 701.

Alus, Sermet Muhtar (1959), “Anastas (K1z)”, İstanbul Ansiklopedisi, C. II, s. 838.

Alus, Sermet Muhtar (1959), “Antoine (André)”, İstanbul Ansiklopedisi, C. II, s. 882.

Alus, Sermet Muhtar (1959), “Araksi Hanım”, İstanbul Ansiklopedisi, c. II, s. 964.

Alus, Sermet Muhtar (1961), "Bayzar Hanım”, İstanbul Ansiklopedisi, ～～C. V, s. 2324.

Alus, Sermet Muhtar (1961), “Binemeciyan (Agavni-zebed)”, İstanbul Ansiklopedisi, C. V, s. 2794.

Alus, Sermet Muhtar (1961), "Binemeciyan (Eliza)”, İstanbul Ansiklopedisi, C. V, s. 2795.

Alus, Sermet Muhtar (1961ç), "Binemeciyan (Onnik)”, İstanbul Ansiklopedisi, C. V, s. 2795.

Alus, Sermet Muhtar (1961), "Binemeciyan (Rupen)”, İstanbul Ansiklopedisi, C. V, s. 2796.

Alus, Sermet Muhtar (1958), “Ahmed (Dönme)”, İstanbul Ansiklopedisi, C. I, s. 307.

Alus, Sermet Muhtar (1958), “Ahmed (Şişko)”, İstanbul Ansiklopedisi, C. I, s. 316.

Alus, Sermet Muhtar (1960), “Aşkî (Kemanî)”, İstanbul Ansiklopedisi, C. III, s. 1170.

Alus, Sermet Muhtar (1958), “Ağavni (Şişman)”, İstanbul Ansiklopedisi, C. I, s. 252.

Amicis, Edmondo de (1993), İstanbul 1884, çev. Beynun Akyavaş, Ankara: Türk Tarih Kurumu Yayınları.

And, Metin (1962), Kavuklu Hamdi'den Üç Orta Oyunu, Ankara: Forum Yayınları.

And, Metin (1976), Osmanlı Tiyatrosu, Ankara: Ankara Üniversitesi DTCF Yayınları.

Dökmeci, Vedia-Çıracı, Hale (1990), Tarihsel Gelişim Sürecinde Beyoğlu, İstanbul: Turing Yayınları.

Es, Hikmet Feridun (2010), Kaybolan İstanbul'dan Hâtıralar, hzl. Selçuk Karakılıç, İstanbul: Ötüken Neşriyat.

Işın, Ekrem (2001), "Bir İçecekten Daha Fazla: Kahve ve Kahvehanelerin Toplumsal Tarihi”, Tanede Saklı Keyif içinde, İstanbul: Yapı Kredi Yayınları. 
Nutku, Özdemir (2015), Darülbedayi'den Şehir Tiyatrosu'na, İstanbul: Türkiye İş Bankası Kültür Yayınları.

Özdemir, Nebi (2005), Cumhuriyet Dönemi Türk Eğlence Kültürü, Ankara: Akçağ Yayınları.

Özhan Koçak, Dilek (2011), 19. Yüzyll İstanbul'unda Kültürel Dönüşümün Sahnesi Osmanlı Tiyatrosu, İstanbul: Parşömen Yayıncılık.

Pekman, Yavuz (2011), Geçmişten Günümüze İstanbul Tiyatroları, İstanbul: Yapı Kredi Yayınları.

Sakaoğlu, Necdet-Akbayar, Nuri (1999), Binbir Gün Binbir Gece, İstanbul: Denizbank Yayınları.

Sevengil, Refik Ahmet (2014), İstanbul Nasıl Eğleniyordu?, İstanbul: Alfa Yayınları.

Tanpınar, Ahmet Hamdi (2004), Beş Şehir, İstanbul: Dergâh Yayınları.

Tanpınar, Ahmet Hamdi (2012), On Dokuzuncu Asır Türk Edebiyatı Tarihi, hzl. Abdullah Uçman, İstanbul: Dergâh Yayınları. 